\title{
Material Implications of Rural Electrification-A Methodological Framework to Assess In-Use Stocks of Off-Grid Solar Products and EEE in Rural Households in Bangladesh
}

\author{
Alexander Batteiger ${ }^{1,2, *}$ and Vera Susanne Rotter ${ }^{2}$ \\ 1 Microenergy Systems Research Group, Technische Universität Berlin, 10623 Berlin, Germany \\ 2 Chair of Circular Economy and Recycling Technologies, Office Z2, Department of Environmental Technology, \\ Technische Universität Berlin, Straße des 17. Juni 135, 10623 Berlin, Germany; vera.rotter@tu-berlin.de \\ * Correspondence: batteiger@ztg.tu-berlin.de
}

Received: 14 December 2017; Accepted: 5 February 2018; Published: 7 February 2018

\begin{abstract}
Universal access to electricity" is proclaimed as the seventh sustainable development goal (SDG 7) of the United Nations (UN) Sustainable Development Goals list. The achievement of this goal will result in a rapid diffusion of energy technologies that would in turn increase materials stocks, subsequently increase the raw material demand as well as the arising waste flows. This study describes a methodological framework to assess in-use stocks of off-grid solar products and electrical and electronic equipment (EEE) for rural communities in developing countries. The methodology is based on energy-access data. Furthermore, the specifics of the characteristics of off-grid solar products are discussed. The methodology is applied to rural Bangladesh and its solar home system (SHS) program. By the end of 2016, around 4.1 million SHSs were installed. This type of access to electricity has a significant impact on the in-use stocks, as households add the comparatively heavy SHSs to their in-use stocks. In-use stocks of EEE, in general, are low. Off-grid solar products are lighter than standard EEE, and fewer products types are available. These findings will help to better understand material stocks and future waste flows in the given context and will support the adaption of recycling infrastructures.
\end{abstract}

Keywords: material stocks; electronic waste; SDG 7; rural electrification; off-grid solar products

\section{Introduction}

In 1878, Thomas Edison demonstrated an incandescent light bulb, imagining that electricity will be so cheap that only the rich will burn candles [1]. Yet, Edison's dream has not materialized for the 1.06 billion people who do not have access to electricity [2]. In 2011, the Sustainable Energy for All initiative was launched by the United Nations to overcome this situation [3]. Finally, in November 2015, universal access to modern energy services, including access to electricity, became the seventh Sustainable Development Goal (SDG 7). Energy, and therefore access to energy, is crucial for achieving almost all SDGs [4].

The vast majority of the global population, without access to electricity, live in rural communities, mostly in sub-Saharan Africa and Southeast Asia [2]. These households rely on kerosene lamps, candles, and increasingly on battery-run flashlights for lighting [5,6]. Access to electricity can be achieved by extending the national grid, developing independent community-level grids, or providing individual household solutions (see Figure 1). For rural off-grid areas, decentralized energy systems based on renewable energies are crucial to achieving SDG 7 [7-10]. On a household level, so-called solar home systems (SHS) are a viable option for electrification [11,12]. An SHS consists of a PV panel, a charge controller, wiring, and a battery. Depending on the system capacity, it provides enough electricity to 
run several LED lamps, a TV, mobile phone chargers, and one or two fans (see Supplementary S1). Shortly, small fridges will be available for SHSs [13].

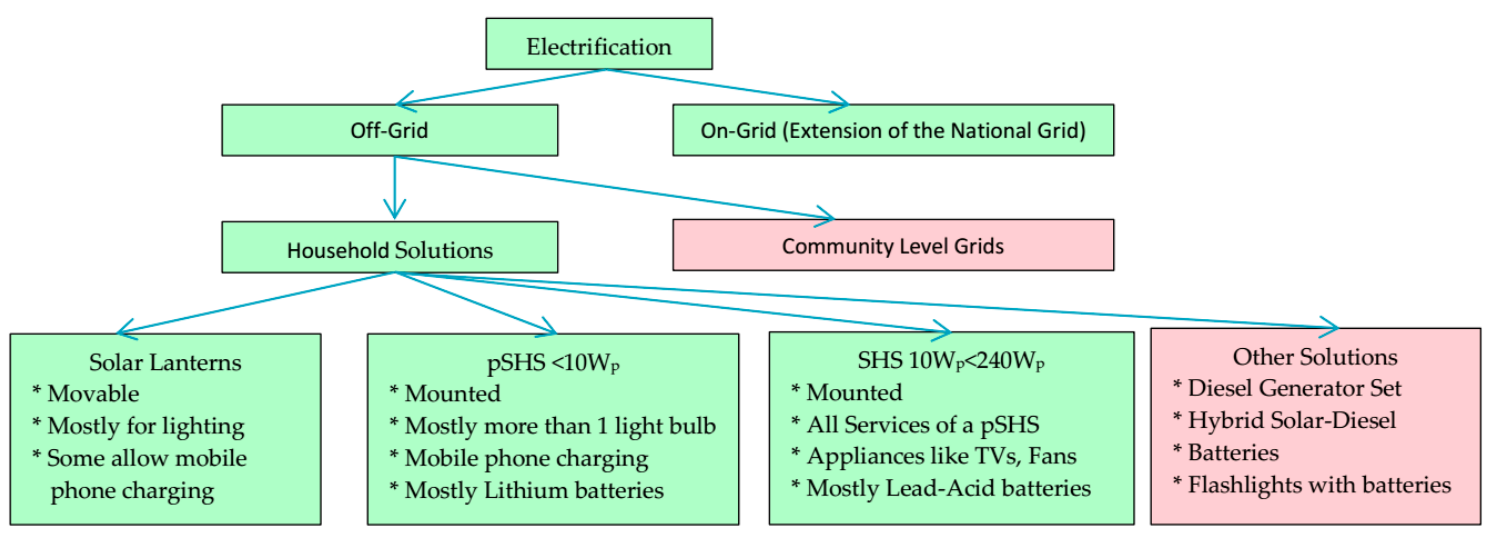

Figure 1. Types of electrification addressing access to electricity deficits in rural communities. Products and types of access marked in green are within the scope of this research (based on [14]).

By the end of 2015, more than five million SHSs were installed globally, with Bangladesh leading the way with 3.6 million installed SHSs at that time [15]. Recently, in countries like India, Ethiopia, Kenya, and Tanzania, SHS industries and markets were established and started to grow rapidly [15]. Additionally, over 40 million solar lanterns were distributed globally in the past years [13,15]. Off-grid technologies are proliferating rapidly in countries with access to electricity deficits. As households gain access to electricity, they climb up the energy ladder and begin to use more electricity-using products (EuP).

In general, access to electricity is viewed as a positive in terms of poverty alleviation and economic development. Nevertheless, a need for integrated problem-oriented research into the relationships between energy service provision and environmental degradation was identified [16]. Furthermore, environmentally sound management of e-waste is either absent or limited in most developing countries [17]. A recent review on the sustainability of off-grid photovoltaic systems for rural electrification identified a lack of environmental awareness and environmental policies [14]. This led to a situation in Ghana and Ecuador, where nonfunctional off-grid solar products including batteries were being buried somewhere [14].

From a material perspective, using SHSs results in material stocks of both energy access products (EAPs) and EuPs. According to Directive 2012/19/EU of the European Parliament and of the Council of 4 July 2012 on waste electrical and electronic equipment (WEEE), both EAPs and EuPs fall under the definition of "electrical and electronic equipment" (EEE) and "waste electrical and electronic equipment" [18]. We refer to all electricity-using products in SHS households as $\mathrm{EuP}_{\mathrm{SHS}}$. SHSs, including the PV panel, the charge controller, the battery, and the cables to connect the equipment, fall into the category of energy access products. The sum of the $\mathrm{EuP}_{\mathrm{SHS}} \mathrm{s}$ and the EAPs in SHS households is referred to as off-grid solar products. Table 1 shows the reference system for all products found in rural households.

Table 1. The reference system for all products found in households $(\mathrm{HH})$ by type of access to electricity.

\begin{tabular}{ccccc}
\hline Type of Household & $\mathbf{H H}_{\text {SHS }}$ & $\mathbf{H H}_{\mathbf{g}}$ & $\mathbf{H H}_{\mathbf{0}}$ & All $\mathbf{H H}$ \\
\hline Electricity-Using Products (EuPs) & $\mathrm{EuP}_{\mathrm{SHS}}$ & $\mathrm{EuP}_{\mathrm{g}}$ & $\mathrm{EuP}_{0}$ & $\mathrm{EuP}$ \\
Energy Access Products (EAPs) & EAP & - & - & - \\
All Products (EuPs + EAPs) & Off-Grid Solar Products & - & - & Electrical and Electronic Equipment (EEE) \\
\hline
\end{tabular}

Note: Households using an solar home system (SHS) as a primary source of access to electricity are referred to as $\mathrm{HH}_{\mathrm{SHS}}$, households having a connection to the electricity grid are referred to as $\mathrm{HH}_{\mathrm{g}}$, and households without access to electricity are referred to as $\mathrm{HH}_{0}$. 
The United Nations Environment Programme (UNEP) Resource Panel described the quantification of todays and future anthropogenic stocks for nonrenewable resources as one of the key tasks for policymakers and society. "The continued increase in the use of metals over the twentieth century has led to a substantial shift from geological resource base to metal stocks in society. Such a shift raises social, economic, and environmental issues that require quantifying the amount of stock of 'metal capital' utilized by society" [19].

A prerequisite for developing sustainable waste management solutions following rural electrification scenarios is the ex-ante quantification of in-use stocks and the characterization of the physical properties of items in the stock [20]. Yet, the impact of access to electricity strategies in developing countries on material stocks in societies has not been in the center of scientific research. Information about in-use stocks of EuPs or EAPs in developing countries is scarce and mostly available at the country level or for urban areas.

The "Energy Sector Management Assistance Program" (ESMAP) of the World Bank and the Sustainable Energy for All initiative presented a new measurement approach for access to electricity [21] which includes a detailed classification for the type of access to electricity as well as the related household's possession of EuPs and EAPs. Furthermore, it differentiates between urban and rural households. This consistent approach will help to harmonize datasets of existing and future possession of EuPs and EAPs in rural communities across developing countries. Studies on the access of electricity will be integrated into regular household surveys in developing countries with electrification deficits.

There is little knowledge about the characteristics of in-use stocks in rural communities of developing countries in general, but knowledge related to new energy access pathways are particularly scarce. Nevertheless, ongoing and accelerating rural electrification requires a good understanding of whether the type of access to electricity strategy impacts future end-of-life management challenges. To link this concept of measuring energy access to the quantification of materials stocks associated with energy access pathways requires specific datasets that are, so far not structured. These datasets provide information about the material properties of off-grid solar products resulting in distinctly different in-use stock characteristics. Thus, the objectives of this research are the following:

- To develop the framework of linking access to electricity metrics with product properties for the assessment of in-use stocks for off-grid solar products and EEE in rural households in developing countries.

- To provide empiric datasets to apply a conceptual framework for a case study in Bangladesh.

- To demonstrate the impact of the type of access to electricity on the material in-use stocks in rural households of developing countries.

The paper outline is as follows. The introduction provides information about access to electricity pathways, the importance of material stocks for decision-making, and the rationale of the developed methodology. It is followed by a literature review and an introduction to the investigated case study: the SHS program of Bangladesh. This publication presents a specific dataset on EuPs and EAPs possession in rural Bangladesh. Through applying the consistent classification approach to the empiric market survey on the properties of EuPs and EAPs the present and future stocks per household could be calculated. Furthermore, the sensitivity of future growth rates on the total stock is investigated. Conclusions are drawn towards the relevant steps to design proper end-of-life strategies for solar home systems and associated waste flows.

\section{Background}

\subsection{Measuring Access to Energy}

The UN Secretary-General's Independent Expert Advisory Group (IEAG) on a Data Revolution for Sustainable Development acknowledged the difficulties of measuring progress towards the Millennium 
Development Goals (MDG) [22]. In the MDG context, rural households using SHSs were counted as not electrified. In order to overcome this situation, the World Bank's Energy Sector Management Assistance Program developed a new measurement approach to measure the access to electricity [21]. A Multitier Framework (MTF) substitutes the binary system of having access to the grid or not. No power source results in a Tier 0 status. Higher consumption and service quality levels lead to a higher tier status (see Table 2). The questionnaire of the survey of the MTF includes the type of access to electricity and the household's possession of EuPs and EAPs. A standard SHS can qualify for a Tier 1 or Tier 2 status, but not for a Tier 3 and above because of the capacity restrictions of SHSs [23]. A verbal description of the framework to determine the tier status of households can be found in the supplementary material (see Supplementary S2). Furthermore, a detailed description of the methodology can be found in References $[21,23,24]$. MTF studies will be integrated into regular household surveys in countries with electrification deficits [2].

Table 2. The multitier framework measurement system for access to household electricity supply combined with a multitier framework system for access to household electricity services (based on [21]).

\begin{tabular}{ccccccc}
\hline & Tier 0 & Tier 1 & Tier 2 & Tier 3 & Tier 4 & Tier 5 \\
\hline Power & - & $\begin{array}{c}\text { Very Low } \\
\text { Power } \\
\text { Min. 3 W }\end{array}$ & $\begin{array}{c}\text { Low Power } \\
\text { Min. 50 W }\end{array}$ & $\begin{array}{c}\text { Medium Power } \\
\text { Min. 200 W }\end{array}$ & $\begin{array}{c}\text { High Power } \\
\text { Min. 800 W }\end{array}$ & $\begin{array}{c}\text { Very High Power } \\
\text { Min. 2 kW }\end{array}$ \\
\cline { 2 - 6 } Capacity & Min. 12 Wh & Min. 200 Wh & Min. 1.0 kWh & Min. 2.4 kWh & Min. 8.2 kWh \\
\hline OR Services & $\begin{array}{c}\text { Not } \\
\text { applicable }\end{array}$ & $\begin{array}{c}\text { Task lighting, } \\
\text { phone } \\
\text { charging }\end{array}$ & $\begin{array}{c}\text { General } \\
\text { lighting, TV, } \\
\text { fan (if needed) }\end{array}$ & $\begin{array}{c}\text { Tier 2 AND any } \\
\text { medium-power } \\
\text { appliances }\end{array}$ & $\begin{array}{c}\text { Tier 3 AND any } \\
\text { high-power } \\
\text { appliances }\end{array}$ & $\begin{array}{c}\text { Tier 4 AND any } \\
\text { very high-power } \\
\text { appliances }\end{array}$ \\
\hline
\end{tabular}

\subsection{Rural Electrification and (E-)Waste}

Stakeholders involved in electrification address the emerging end-of-life problem mostly in terms of e-waste management. "Lighting Global" published Eco-Design Notes referring to battery toxicity, ecoproduct design, restriction of hazardous substances, and life-cycle management options [25]. The "Global Off-Grid Lighting Association" stressed the importance of extended producer responsibility [26]. Schützeichel [27] proposed that either recycling concepts should be integrated directly into the tender processes or that opinion leaders like the World Bank should put the development of appropriate standards and rules on their agenda. At the fourth Off-Grid Lighting Conference a session was dedicated to "environmental and social sustainability across the value chain", highlighting the overall environmental and social benefits and the remaining challenges in turning the sector into a 100\% circular economy [28]. The annual estimated off-grid solar waste generation was around $800 \mathrm{Mg}$ in 2014 or $0.5 \%$ of the generated e-waste in 14 African countries [29]. Yet, it was a negligible number.

\subsection{E-Waste Definition}

Up to now, there is no universally accepted definition of e-waste [30-32]. The Solving the E-waste Problem initiative (STEP), which develops sustainable solutions for e-waste management in developing countries, defines e-waste as follows [31]: "E-Waste is a term used to cover items of all types of electrical and electronic equipment (EEE) and its parts that have been discarded by the owner as waste without the intention of re-use". Furthermore, to classify and assess types and streams of e-waste, the UNU-Keys was developed by the United Nations University [30]. E-waste statistics should categorize products by their characteristics like function, material composition, and related to the end-of-life attributes. Additionally, products within the same category should have a homogeneous average weight and lifespan distribution to simplify quantitative assessments for similar products. Large or environmentally-relevant e-waste products should be assigned separately [30]. 
This classification approach does not distinguish between EuPs and EAPs used by grid-connected households and/or SHS-using households.

\subsection{Assessing and Estimating E-Waste Generation}

Global e-waste generation is estimated between 20 and 50 million metric tonnes per year [33-35]. It is considered one of the fastest growing solid waste flows on a global scale [36]. Additionally, trends towards e-mobility including electric vehicles and e-bikes [37] and increasing installations of solar PV contribute to this development [38]. On the other hand, technological innovation can decrease the expected waste-flows by lowering the average weight of devices. Examples are the shift from desktop computers to laptops or liquid crystal displays (LCD)/light-emitting diode (LED) displays in TVs instead of cathode ray tube (CRT) TVs [30].

E-waste management is an emerging problem of increasing importance in developing and developed countries [35,39-41]. For developing countries, it is a business opportunity, given the rising volumes of EEE being generated/imported and the reuse and material value of the EEE [30,40]. At the same time, informal material recovery, incineration, and improper disposal in landfills poses a serious toxic threat $[18,42,43]$ and leads to resource losses [44].

According to Wang et al. [45], e-waste estimation methods can be classified into four groups. Firstly, the disposal-related analysis uses data obtained from official collection channels. Secondly, time series analysis extrapolates historical sales data into the future using historic lifespan data to estimate future e-waste generation and was used by References [41,46-48]. Thirdly, factor models analyze relationships between factors like population size, income levels, GDP versus e-waste generation and was used in References $[34,49,50]$. The fourth group of estimation methods is input-output analysis and is the most commonly applied methodology to estimate e-waste generation [45]. Domestic flows and exports of used computers in the USA were analyzed [51]. Steubing et al. [52] estimated the waste material from desktops and laptop personal computers in Chile. Andarani and Goto [53] used dynamic material flow analysis and stated that they expected the e-waste generation to triple in the decade from 2015-2035 in Indonesia. Streicher-Porte et al. [54] analyzed the gold and copper flows for obsolete PCs in India and found material flow analysis (MFA) to be a suitable tool for e-waste estimation in the context of limited data. Chancerel and Rotter [55] analyzed the flows of copper and precious metals in e-waste preprocessing plants in Germany. Lam et al. [56] found MFA to be capable of estimating future e-waste generation from televisions, even if the technologies are substituted over time. Additionally, obsolete personal computers from different higher education institutions in developing countries were compared [57]. Lau et al. [58] estimated the WEEE generation of Hong Kong using MFA. Mishima et al. [59] applied material flow analysis to examine strategies for reducing material consumption associated with mobile phone usage and end-of-life management. Hamouda et al. [41] highlighted the lack of consistent data monitoring in developing and emerging countries leading to uncertain information about material stocks and flows.

The growing access to electricity is a process. One of the results of the process is accelerating EAP and EuP ownership and in the long run, e-waste generation. Yet, e-waste estimation methodologies mostly focus on a product level, either for one EuP or a cluster of EuPs. Furthermore, e-waste assessments in developing countries have been mostly carried out for urban areas. Rural communities of developing countries and access to electricity pathways have not been in the focus of the scientific discussion.

\subsection{Research Trends for Rural Electrification and Off-Grid Energy Systems with a Focus on Environmental Impacts}

In recent years, the number of publications regarding off-grid electrification has been growing rapidly. Most literature focuses on the technology and the institutional setting. User-centered research and financial viability are also of interest but are less researched [60]. The few publications on environmental and human health impacts of off-grid electrification indicate positive impacts, depending highly on scenarios for the end-of-life management for batteries [61], the lifespan of the products, and the institutional and economic success of the electrification programs [14]. Alstone [62] found energy 
payback times of off-grid lighting technologies between 20 and 50 days and energy return on investment ratios from 10 to 40. Magalini et al. [29] found solar lanterns to be a negligible stream of e-waste in African countries. Furthermore, technologies like battery powered LED-torches and kerosene lamps, among others, are replaced [14]. Stojanovski et al. [63] interviewed SHS adopters and found only a small decrease in spending on dry-cell batteries, as EuPs already in the households were not plug-and-play with the SHS and still in use. Bensch et al. [5] identified battery powered torches as an emerging waste management problem, as they are the default option for lighting in Ruanda and Senegal and latrines are being used for the disposal of the batteries. Furthermore, the quality of the torches sold on rural markets is low, resulting in average lifespans of less than two months [6]. The sustainability potential of the business models for delivering distributed renewable energies was highlighted [64]. Yet, waste management systems or regulation for products like torches and batteries, radios or solar off-grid products, in general, are mostly not in place [14].

\subsection{Case Study: Bangladesh and the Local SHS Program}

Bangladesh is a low-middle income economy with more than 160 million inhabitants (see Table 3). Excluding city-states, it is the country with the highest population density of the world. Yet, around 60 million people are not connected to the national electricity grid. The SHS program started in 2003 as a small-scale World Bank intervention to foster access to electricity for rural households. Intelligent service provision schemes, strong institutions, microfinance, and local technology development resulted in a successful intervention [12]. The SHS program created local PV-panel producers, strengthened the local battery industry, and employs approximately 127,000 people $[65,66]$. Notably, environmental impact mitigation was achieved through a prequalification process for technology suppliers, setting environmental and occupational standards in the local battery and solar industry [65]. Price levels for PV panels, batteries, and energy efficient appliance EUPs like LED lamps or LCD TVs decreased rapidly in a few years [67]. As a result, by 2013, the program was financially sustainable and most subsidies were abolished [12]. In July 2016 the number of installed SHSs financed through the program exceeded four million [68]. Additionally, an over-the-counter market for SHSs arose. The total installed off-grid solar capacity, predominantly from SHSs, is $185 \mathrm{MW}_{\mathrm{p}}$ [69]. In 2014, around $15 \%$ of rural households and $3 \%$ of urban households used solar technologies as their primary source of electricity [70]. The goal of the Bangladeshi government is to achieve universal access to electricity by 2021. The target of the SHS program is six million installed SHSs by 2021 [71].

Table 3. Key indicators in 2015 of Bangladesh compared to Germany; (all data: [72], except access to electricity [70]).

\begin{tabular}{ccc}
\hline Indicator & Bangladesh & Germany \\
\hline Population (million) & 160.9 & 81.4 \\
Urban Population (\%) & 34 & 75 \\
Land Area (km ${ }^{2}$ ) & 130,170 & 348,540 \\
Population Density (people per km ${ }^{2}$ ) & 1237 & 234 \\
GDP (current Billion US\$) & 195.1 & 3363.4 \\
GDP per Capita (current US\$) & 1211 & 41,313 \\
Access to Electricity in 2014 rural/urban/total (in \%) & $51 / 91 / 62$ & Universal \\
Electric Power Consumption in 2013 (kWh per capita) & 293 & 7019 \\
\hline
\end{tabular}

Already in 2010, the first steps regarding the end-of-life management of SHSs were taken and the local SHS program was identified as an emerging source of scrap lead in the national 3-R Strategy [73]. Regarding environmental concerns, the improper disposal of lead-acid batteries, PV panels, and CFL bulbs was highlighted as the most pressing topic [74].

Information about the formal and informal e-waste management, in-use stocks or even the flows of EEE or e-waste generation in Bangladesh is scarce. In 2014, the per capita e-waste generation of 
Bangladesh was estimated to be $0.8 \mathrm{~kg}$ per capita or $124 \mathrm{Gg}$ [35]. A Bangladeshi NGO estimates the local annual e-waste generation at $1240 \mathrm{Gg}$, mostly from TVs and household appliances [75]. Furthermore, the shipbreaking industry and illegal imports add significant amounts of e-waste. Most of the e-waste in Bangladesh is sourced from abroad for re-use, repair, and material recovery [76,77]. Yet, there is only a rudimentary legal framework and inventory for e-waste management in Bangladesh $[35,78,79]$. Additionally, little awareness regarding human health aspects of e-waste management was found [80,81]. If available, the information is accessible only at the country level or for urban areas.

\section{Materials and Methods}

\subsection{Methodological Approach and Research Design}

The quantification methodology for in-use stocks was based on data from access-to-electricity surveys that include information about the household possession of EuPs and EAPs. These surveys provided further information about the capacities of used SHSs. The data from the surveys were compared to data on the household possession of EuPs in rural communities from the World Bank's Demographic and Health Surveys (DHS).

Secondly, an extensive market and literature review regarding off-grid solar product properties was conducted in order to characterize and categorize them. Based on the market research, capacity-specific weights for the EAPs were calculated. This resulted in estimations of the total in-use stocks of EEE at a household level.

In order to determine the impact of the type of access to electricity, the in-use stocks were statistically analyzed. The results are clustered by type of electrification and compared to in-use stocks clustered by tier status and income. Furthermore, the clusters were analyzed by the percentage that each type of EuP and EAP contributes to the total in-use stock of the cluster. Finally, a sensitivity analysis based on different scenarios was conducted. Figure 2 describes the research design.

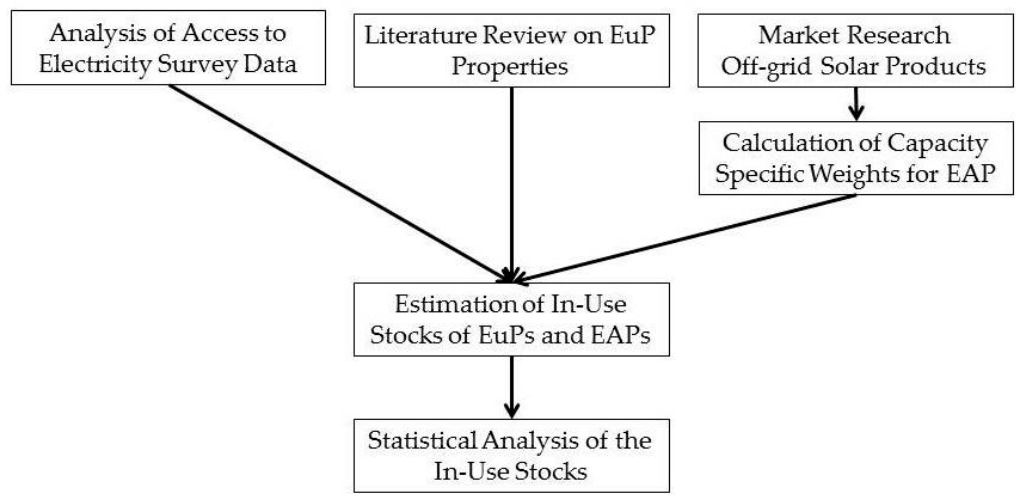

Figure 2. The research design.

\subsection{Used Dataset: Access-to-Electricity Survey in Rural Bangladesh}

Access-to-electricity survey data was gratefully provided for this research by Groh et al. [23]. A sample of 231 rural Bangladeshi households was surveyed. Field selection was performed using a top-down methodology. One random district was drawn from the northern, central, and southern Bangladesh areas. The generic underlying questionnaire of the MTF provided by the ESMAP was used (see Supplementary S9). Within the sample, 54 households $(\mathrm{HH})$ had no primary access to electricity $\left(\mathrm{HH}_{0}\right), 110$ had SHSs $\left(\mathrm{HH}_{\mathrm{SHS}}\right), 69$ were grid-connected $\left(\mathrm{HH}_{\mathrm{g}}\right), 5$ used diesel, and 5 used other technologies. Eleven households of the sample reported having an SHS and access to the grid $\left(\mathrm{HH}_{\mathrm{SHS}+\mathrm{g}}\right)$. The tier status of the households was retrieved from the same survey (see Supplementary S3). Access to electricity in rural areas in Bangladesh was 51\% in 2014 (see Table 3) 
but only $29.8 \%$ in the survey. Furthermore, the SHSs are overrepresented. The selected districts had lower access to electricity rates than the average rural communities. Thus, the sample itself is not representative of rural Bangladesh as a whole. Yet, the selected districts are areas where rural electrification took place in recent years. In order to validate the results, information about the possession of EEE was compared to DHS surveys [70,82-84].

\subsection{Data Collection Weights of EEE and Categorization and Characterization for Off-Grid Solar Products}

Literature values for the average weight were retrieved from the Global E-Waste Monitor [30,35] and compared to $[34,75,85]$ for $\mathrm{HH}_{\mathrm{g}}$. Data for off-grid solar products were collected by an extensive market research including the product catalog of the off-grid solar product retailer (www.phaesun.com) and a database for off-grid solar products (http:/ / sendea.biz/) which links to the company homepages of off-grid solar distributors. All detailed datasets regarding off-grid solar products properties can be found in the supplementary materials (see Supplementary S4). The categorization of off-grid solar products is finally discussed.

\subsection{Calculation of the In-Use Stocks of EEE and Off-Grid Solar Products}

The in-use stocks are calculated on an individual $\mathrm{HH}$ basis and expressed in $\mathrm{kg} / \mathrm{HH}$. A list of all assumptions can be found in the supplementary material (see Supplementary S7). The in-use stocks for SHS households $\mathrm{m}_{\mathrm{SHS}}$ were calculated by multiplying the number of $\mathrm{EuP}_{\mathrm{SHS}} \mathrm{n}_{\mathrm{j}}$ by the average weight $\overline{m_{j}}$ of the EuP $P_{S H S}$. The average weight of $\operatorname{EuP}_{S H S} \overline{m_{j}}$ was calculated based on the values from the market research. Furthermore, the weight of the EAP $\mathrm{m}(\mathrm{c})_{\mathrm{SHS}}$ and one cable for every EuP $\mathrm{SHS}_{\mathrm{S}}$ in use $\overline{\mathrm{m}}_{\mathrm{w}}$ is added.

$$
\mathrm{m}_{\mathrm{hhSHS}}=\sum_{\mathrm{j}=1}^{\mathrm{x}}\left(\mathrm{n}_{\mathrm{j}} * \overline{\mathrm{m}_{\mathrm{j}}}\right)+\sum_{\mathrm{k}=1}^{\mathrm{y}}\left(\mathrm{n}_{\mathrm{k}} * \mathrm{~m}(\mathrm{c})_{\mathrm{SHS}}\right)+\left(\mathrm{n}_{\mathrm{j}}+\mathrm{n}_{\mathrm{k}}\right) * \overline{\mathrm{m}_{\mathrm{w}}}
$$

The mass of the EAP $\mathrm{m}(\mathrm{c})_{\mathrm{SHS}}$ is the sum of the weights of the PV panel $\mathrm{m}(\mathrm{c})_{\mathrm{pv}}$, the battery $\mathrm{m}(\mathrm{c})_{\text {batt }}$, the charge controller $\overline{\mathrm{m}}_{\mathrm{CC}}$, and the wiring $\mathrm{m}_{\mathrm{wSHS}}$ (see Equation (2)). $\mathrm{m}(\mathrm{c})_{\mathrm{pv}}$ and $\mathrm{m}(\mathrm{c})_{\text {batt }}$ depend on the capacity of the SHS. The capacity specific weight of PV panels and batteries was calculated by linear regression based on datasets from the market research (PV panel $n_{p v}=70$; battery $n_{\text {batt }}=113$; see Supplementary S5) in order to determine the coefficients for Equations (3) and (4). The capacity of the battery is between 1 and 1.5 times the capacity of the PV panel [86,87]. The chosen parameter for the modeling was 1.25 .

$$
\begin{gathered}
\mathrm{m}(\mathrm{c})_{\mathrm{SHS}}=\mathrm{m}(\mathrm{c})_{\mathrm{pv}}+\mathrm{m}(\mathrm{c})_{\text {batt }}+\overline{\mathrm{m}}_{\mathrm{CC}}+\mathrm{m}_{\mathrm{wSHS}} \\
\mathrm{m}(\mathrm{c})_{\mathrm{pv}}=0.08 \times \mathrm{cSHS}+0.68 \\
\mathrm{~m}(\mathrm{c})_{\text {batt }}=0.28 \times\left(1.25 \times \mathrm{c}_{\mathrm{SHS}}\right)+2.51
\end{gathered}
$$

The in-use stocks for $\mathrm{HH}$ not having an SHS $\mathrm{m}_{\mathrm{hh}}$ were calculated by multiplying the number of EuPs $n_{i}$ with the average weight $\overline{m_{i}}$ of the EuPs. Furthermore, for any EuP found in an $\mathrm{HH}$, a cable $\overline{\mathrm{m}}_{\mathrm{w}}$ is added to the in-use stock (see Equation (5)):

$$
\mathrm{m}_{\mathrm{hh}}=\sum_{\mathrm{i}=1}^{\mathrm{n}}\left(\mathrm{n}_{\mathrm{i}} \times \overline{\mathrm{m}_{\mathrm{i}}}\right)+\mathrm{n}_{\mathrm{i}} \times \overline{\mathrm{m}}_{\mathrm{w}}
$$

The in-use stocks for $\mathrm{HH}$ being connected to the grid and owning SHS $\mathrm{m}_{\mathrm{hhSHS}+\mathrm{g}}$ are the sum of the stocks $\mathrm{m}_{\mathrm{hh}}$ and $\mathrm{m}_{\mathrm{hhSHS}}$ :

$$
\mathrm{m}_{\mathrm{hhSHS}+\mathrm{g}}=\mathrm{m}_{\mathrm{hh}}+\mathrm{m}_{\mathrm{hhSHS}}
$$




\subsection{Statistical Analysis}

In order to analyze the impact of the type of access to electricity, the results are clustered by the type of electrification (no primary access, SHS, and grid). Furthermore, the results by type of electrification are compared to results clustered by the Tier status (Tiers $0-5$ ) and the income quantiles of the households. Access to electricity and the diffusion of off-grid solar technologies are highly dynamic processes. Thus, the robustness of the aggregated results for the in-use stocks is tested by a variation of single parameters. The variation is based on scenarios of changing patterns that have been already observed in the given context.

\section{Results}

\subsection{Household Possession}

\subsubsection{Household Possession of EuPs and EAPs}

The possession of EuPs and EAPs is very low in rural Bangladesh. None of the HHs possess an electric cooking system, washing machine, dishwasher, printer, air conditioning system, electric food processor, radio, DVD-player, water heater, electric hair dryer, microwave, toaster, or any other EuP mentioned in Table 4. The only EuPs being found universally in the sample are mobile phones. Furthermore, all households with access to electricity have electric lighting systems. Within the 10 households categorized as other, one household has a grid connection and is using a diesel generator. Thus, the sum of the connections is higher than the total number of assessed households. Households not having a grid connection or an SHS were excluded from the analysis as the sample size was too small. Based on the low possession of EuPs for $\mathrm{HH}_{\mathrm{g}}$ and $\mathrm{HH}_{\mathrm{SHS}}$, it can be assumed that $\mathrm{HH}_{0}$ does not possess any EuPs in significant numbers. The normalized data refer to $51 \%$ with a grid connection, $15 \%$ with an SHS, and $34 \%$ without access to electricity, representing the access-to-electricity rates in rural Bangladesh.

Table 4. Household possession (at least one) of electricity-using products (EuPs) over the type of electrification (in percentages). The possession of EuPs of households without access to electricity was assumed to be zero. The normalized data refer to $51 \%$ with a grid connection, $15 \%$ with an SHS, and $34 \%$ without access to electricity [70].

\begin{tabular}{ccccccc}
\hline $\begin{array}{c}\text { Household } \\
\text { Possession of EuPs } \\
\text { (at Least One) }\end{array}$ & $\begin{array}{c}\text { No-Electricity } \\
(\mathbf{n}=\mathbf{5 4})\end{array}$ & $\begin{array}{c}\text { SHS (Excl. } \\
\text { SHS + Grid) } \\
(\mathbf{n}=\mathbf{9 9 )}\end{array}$ & $\begin{array}{c}\text { Grid (Excl. } \\
\text { SHS + Grid) } \\
(\mathbf{n}=\mathbf{5 8})\end{array}$ & $\begin{array}{c}\text { SHS + Grid } \\
(\mathbf{n}=\mathbf{1 1})\end{array}$ & $\begin{array}{c}\text { Other } \\
(\mathbf{n}=\mathbf{1 0})\end{array}$ & Normalized \\
\hline Electrical Lighting & - & $100 \%$ & $100 \%$ & $100 \%$ & $50 \%$ & $66 \%$ \\
Mobile Phone & $100 \%$ & $100 \%$ & $100 \%$ & $100 \%$ & $100 \%$ & $100 \%$ \\
Phone Charger & - & $41 \%$ & $58 \%$ & $81 \%$ & $10 \%$ & $36 \%$ \\
Black and White TV & - & $11 \%$ & $2 \%$ & $9 \%$ & - & $4 \%$ \\
Color TV & - & $1 \%$ & $30 \%$ & $18 \%$ & $10 \%$ & $16 \%$ \\
Electric Fan & - & $41 \%$ & $78 \%$ & $81 \%$ & $30 \%$ & $46 \%$ \\
Computer & - & - & $5 \%$ & - & - & $3 \%$ \\
Refrigerator & - & - & $15 \%$ & - & - & $8 \%$ \\
Hair Dryer & - & - & $3 \%$ & - & - & $2 \%$ \\
Rice Cooker & - & - & $3 \%$ & - & - & $2 \%$ \\
Iron & - & - & $5 \%$ & - & - & $3 \%$ \\
Sound Box & - & - & $3 \%$ & - & - & $2 \%$ \\
\hline
\end{tabular}

As within the complete sample, the possession of EuPSHS and EAPs in $\mathrm{HH}_{\mathrm{SHS}}$ is very low. The two most common EuP $\mathrm{SHS}_{\mathrm{SH}}$ are electric fans and phone chargers. Still, 59\% of the SHS users charge their mobile phones outside of their homes. Less than $15 \%$ of $\mathrm{HH}_{\mathrm{SHS}}$ possessed a TV and most of them that did, own a small black and white CRT TV [88]. Only one HH $\mathrm{H}_{\mathrm{SHS}}$ possessed a color TV. The lack of $\mathrm{EuP}_{\mathrm{SHS}}$ ownership can be explained by two factors. Firstly, the operating current of an SHS is

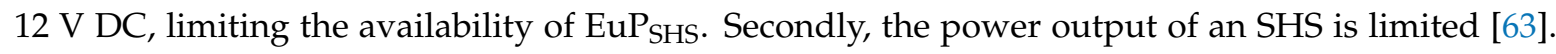


Consequently, heat exchanging $\mathrm{EuP}_{\mathrm{SHS}}$ like a refrigerator, iron, or a rice cooker are currently hardly available for SHSs.

Compared to $\mathrm{HH}_{\mathrm{SHS}}$, grid-connected $\mathrm{HH}_{\mathrm{g}}$ have higher access to EuPs. All $\mathrm{HH}_{\mathrm{g}}$ have access to lighting technologies, $74 \%$ have access to electric fans, and $32 \%$ possess a TV at home. Only $12 \%$ possess a refrigerator, $5 \%$ a computer, and few have a rice cooker, iron, or a sound box. Other high $\mathrm{EuP}_{\mathrm{g}}$ were not found in $\mathrm{HH}_{\mathrm{g}}$. Eleven households have an SHS and grid connection. The sample size in the case of $\mathrm{HH}_{\mathrm{SHS}+\mathrm{g}}$ is small but indicates that households either keep their SHSs when the grid arrives or pay for an SHS even when they are grid-connected.

There are two differences between $\mathrm{HH}_{\mathrm{SHS}}$ and $\mathrm{HH}_{\mathrm{g}}$. The vast majority of black and white TVs are found in $\mathrm{HH}_{\mathrm{SHS}}$, whereas grid-connected households largely own color TVs (see Table 4). For recently installed SHSs however, the results differ, as TVs being distributed with SHSs are nowadays exclusively LED or LCD color TVs (see Supplementary S1). Incandescent light bulbs are not found in $\mathrm{HH}_{\mathrm{SHS}}$, whereas over $15 \%$ of $\mathrm{HH}_{\mathrm{g}}$ use these for lighting. Interestingly, the most expensive lighting technology (LEDs) is almost exclusively found in $\mathrm{HH}_{\mathrm{SHS}}$ (see Figure 3). CFL tube lights are predominantly found in $\mathrm{HH}_{\mathrm{SHS}}$, whereas $\mathrm{CFL}$ light bulbs dominate the grid-connected households. The motivation for energy efficiency has two drivers. Firstly, energy efficient $\mathrm{EuP}_{\mathrm{SHS}}$ lead to smaller SHS capacities and thus lower investment costs for an SHS. Secondly, existing SHSs will be able to deliver more energy

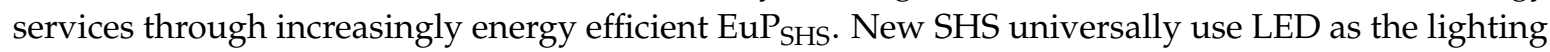
technology (see Supplementary S1). Consequently, CFL technology for $\mathrm{HH}_{\mathrm{SHS}}$ will be phased out in the long run.

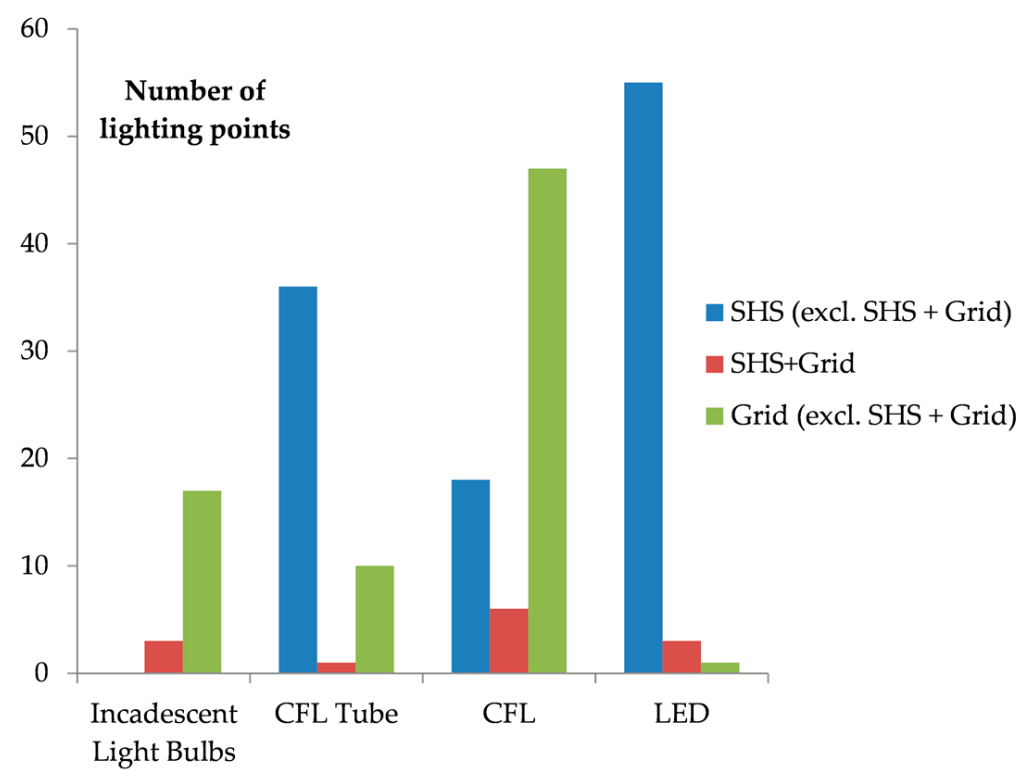

Figure 3. The number of lighting points over the type of lighting point found in households using a solar home system (SHS) as a primary source of access to electricity $\left(\mathrm{HH}_{\mathrm{SHS}}\right)$, households having a connection to the electricity grid $\left(\mathrm{HH}_{\mathrm{g}}\right)$, and households using a SHS and a connection to the electricity grid $\left(\mathrm{HH}_{\mathrm{SHS}+\mathrm{g}}\right)$. More than one lighting point per household is possible.

\subsubsection{Household Possession of EuPs Based on the Demographic and Health Surveys}

The last four demographic and health surveys include aggregated representative data about household possession of EuPs for rural and urban areas in Bangladesh [70,82-84]. The quantity of data, as well as the possession of $\mathrm{EuP}_{\mathrm{SHS}}$, increased over time (see Table 5). Mobile phone possession in rural Bangladesh grew from 1.8\% to 86.7\% from 2004 to 2014. TV possession in rural Bangladesh doubled in the same time. However, only one-third of rural households possess at least one TV, half of them an electric fan and only $12.3 \%$ own a refrigerator. Computer possession and usage in 
rural Bangladesh is still in the single digits. Furthermore, the EuPs ownership by large households in Bangladesh remains very low and limited to very basic services. In the used access-to-electricity dataset, less high electricity-using products like refrigerators or TVs are found. This was expected as the surveyed households are in areas with lower than average rural access to electricity rates [23]. The normalized data of the access to energy survey fit most of the DHS survey data for low energy consuming appliances (compare Table 4).

Table 5. The percentage of households possessing EuPs, by residence in Bangladesh from 2004 to 2014 [70,82-84].

\begin{tabular}{|c|c|c|c|c|c|c|c|c|c|c|c|c|}
\hline \multirow{3}{*}{$\begin{array}{c}\begin{array}{c}\text { Households Possessing } \\
\text { EuPs (\%) }\end{array} \\
\text { Year }\end{array}$} & \multicolumn{8}{|c|}{ Residence } & \multirow{2}{*}{\multicolumn{4}{|c|}{ Total }} \\
\hline & \multicolumn{4}{|c|}{ Urban } & \multicolumn{4}{|c|}{ Rural } & & & & \\
\hline & 2004 & 2007 & 2011 & 2014 & 2004 & 2007 & 2011 & 2014 & 2004 & 2007 & 2011 & 2014 \\
\hline TV & 49.1 & 59.3 & 70.2 & 70.6 & 15.5 & 21.9 & 29.8 & 33.0 & 22.9 & 30.0 & 39.9 & 43.5 \\
\hline Mobile Telephone & \multirow{2}{*}{15.6 * } & 54.7 & 89.2 & 93.4 & & 25.3 & 74.8 & 86.7 & \multirow{2}{*}{$4.8^{*}$} & 31.7 & 78.4 & 88.5 \\
\hline Non-Mobile Telephone & & 7.0 & 7.6 & 4.2 & $1.8^{*}$ & 0.2 & 0.3 & 0.5 & & 1.7 & 2.1 & 1.6 \\
\hline DVD/VCD Player & - & - & 23.8 & 12.1 & - & - & 8.1 & 4.8 & - & - & 12.1 & 6.8 \\
\hline Electric Cooking Equipment & - & - & 0.5 & 1.2 & - & - & 0.0 & 0.1 & - & - & 0.1 & 0.4 \\
\hline IPS/Generator & - & - & - & 7.1 & - & - & - & 1.0 & - & - & - & 2.7 \\
\hline Air Conditioning & - & - & - & 1.3 & - & - & - & 0.1 & - & - & - & 0.4 \\
\hline Computer/Laptop & - & - & - & 11.8 & - & - & - & 2.4 & - & - & - & 5.1 \\
\hline
\end{tabular}

${ }^{*}$ No differentiation between mobile telephones and none-mobile telephones.

\subsection{Material Properties of Off-Grid Solar Products}

Off-grid solar products are significantly lighter than regular EuPs (see Table 6). An average LCD or LED TV for off-grid solar systems weighs $3.2 \mathrm{~kg}$, whereas TVs for on-grid purposes with the same technology have an average weight between $7.9 \mathrm{~kg}$ and $14.3 \mathrm{~kg}$. For radios, the difference is even higher. The availability of off-grid solar products in rural Bangladesh is currently limited to lighting technologies, electric fans, and TVs. The calculated weight of the PV panel for a small $\left(15 \mathrm{~W}_{\mathrm{p}}\right)$, medium $\left(50 \mathrm{~W}_{\mathrm{p}}\right)$ or large SHS $\left(110 \mathrm{~W}_{\mathrm{p}}\right)$ is $1.9 \mathrm{~kg}$, $4.7 \mathrm{~kg}$, or $9.5 \mathrm{~kg}$, respectively. Depending on the capacity of the SHS, it is between one-tenth and less than half of the weight of the literature values for PV panels. Refrigerators will be available soon. In most cases, DC fridges will be distributed with an additional PV panel. Like for all other products, the average weight is significantly lower than the literature values.

\subsection{In-Use Stocks of EuPs and EAPs}

The in-use stocks of EuPs and EAPs within the surveyed sample are very low. The median possession of EEE is $14.1 \mathrm{~kg}$ per $\mathrm{HH}$ or around $3 \mathrm{~kg}$ per capita (see Figure 4). It is less than half the weight of a refrigerator. The few households with stocks above $100 \mathrm{~kg}$ are statistical outliers. These outliers possess a lot in the given context, but very little compared to western households [89]. The median in-use stock of $\mathrm{HH}_{\mathrm{g}}$ is $7.1 \mathrm{~kg}$, thus inclusive of some lighting equipment and some small equipment like a fan or a rice cooker. Of the $\mathrm{HH}_{\mathrm{g}}, 36 \%$ use the grid just for lighting and mobile phone charging. Based on the possession of $\mathrm{EuP}_{\mathrm{g}}$, recently electrified $\mathrm{HH}_{\mathrm{g}}$ should contribute very little to local e-waste generation as the in-use stocks of $\mathrm{EuP}_{\mathrm{g}}$ are very low. 
Table 6. The average weight of off-grid solar products based on market research data compared to literature values for electrical and electronic equipment (EEE)/(electricity-using products in grid-connected households) $\mathrm{EuP}_{\mathrm{g}}$.

\begin{tabular}{|c|c|c|c|c|c|c|c|}
\hline & \multirow{2}{*}{$\begin{array}{c}\begin{array}{c}\text { Off-Grid Solar } \\
\text { Products }\end{array} \\
\text { Average } \\
\text { Weight (kg) }\end{array}$} & \multicolumn{6}{|c|}{ Electrical and Electronic Equipment (EEE) and EuPs } \\
\hline & & Category (35) & UNU-Key (35) & $\begin{array}{c}\text { Average } \\
\text { Weight } \\
\text { (kg) (35) }\end{array}$ & $\begin{array}{l}\text { Average } \\
\text { Weight } \\
\text { (kg) (75) }\end{array}$ & $\begin{array}{l}\text { Average } \\
\text { Weight } \\
\text { (kg) (34) }\end{array}$ & $\begin{array}{c}\text { Average } \\
\text { Weight } \\
\text { (kg) (85) }\end{array}$ \\
\hline $\begin{array}{l}\text { Lighting } \\
\text { (bulb only) }\end{array}$ & 0.07 & Lamps & $\begin{array}{l}0501,0502, \\
0503,0505\end{array}$ & 0.1 & - & - & - \\
\hline $\begin{array}{c}\text { Lighting } \\
\text { (bulb + shadowing } \\
+ \text { cable })\end{array}$ & 0.36 & Lamps & $\begin{array}{c}0501,0502, \\
0503,0505(?)\end{array}$ & $0.1(?)$ & - & - & - \\
\hline Charge Controller & 0.25 & $\begin{array}{c}\text { Small } \\
\text { equipment }\end{array}$ & $0002(?)$ & ? & - & - & - \\
\hline Fan & 2.7 & $\begin{array}{c}\text { Small } \\
\text { equipment }\end{array}$ & $0201(?)$ & 0.8 & - & - & - \\
\hline TV CRT & 8 & Screens & 0407 & 28.4 & & 30 & 31 \\
\hline TV LED/LCD & 3.2 & Screens & 0408 & 14.3 & 15 & - & 7.9 \\
\hline Radio & 0.68 & $\begin{array}{c}\text { Small } \\
\text { equipment }\end{array}$ & 0403 & 3.4 & - & 2 & 3.4 \\
\hline $\begin{array}{c}\text { Solar Lantern } \\
\left(<10 \mathrm{~W}_{\mathrm{p}}\right)\end{array}$ & 1.9 & $\begin{array}{c}\text { Small } \\
\text { equipment }\end{array}$ & (?) & $?$ & - & - & - \\
\hline $\begin{array}{l}\text { Refrigerator } \\
(<501)\end{array}$ & 20.0 * & $\begin{array}{l}\text { Cooling and } \\
\text { freezing }\end{array}$ & 0108 & 54.1 & 100 & 35 & 61 \\
\hline $\begin{array}{c}\text { Panel Small SHS } \\
\left(15 \mathrm{~W}_{\mathrm{p}}\right)\end{array}$ & $1.9 * *$ & $\begin{array}{c}\text { Large } \\
\text { equipment }\end{array}$ & 0002 & 20 & - & - & - \\
\hline $\begin{array}{l}\text { Panel Medium } \\
\text { SHS }\left(50 \mathrm{~W}_{\mathrm{p}}\right)\end{array}$ & $4.7^{* *}$ & $\begin{array}{c}\text { Large } \\
\text { equipment }\end{array}$ & 0002 & 20 & - & - & - \\
\hline $\begin{array}{c}\text { Panel Large SHS } \\
\left(110 \mathrm{~W}_{\mathrm{p}}\right)\end{array}$ & $9.5^{* *}$ & $\begin{array}{c}\text { Large } \\
\text { equipment }\end{array}$ & 0002 & 20 & - & - & - \\
\hline $\begin{array}{l}\text { Battery Small SHS } \\
\text { (20 Ah) }\end{array}$ & $8.1^{* *}$ & - & - & - & - & - & - \\
\hline $\begin{array}{l}\text { Battery Medium } \\
\text { SHS (60 Ah) }\end{array}$ & $19.3^{* *}$ & - & - & - & - & - & - \\
\hline $\begin{array}{l}\text { Battery Large SHS } \\
\text { (140 Ah) }\end{array}$ & $41.7^{* *}$ & - & - & - & - & - & - \\
\hline
\end{tabular}

The median in-use stock of $\mathrm{HH}_{\mathrm{SHS}}$ is $25.1 \mathrm{~kg}$. Even though the possession of $\mathrm{EuP}_{\mathrm{SHS}}$ for $\mathrm{HH}_{\mathrm{SHS}}$ is lower than for $\mathrm{HH}_{\mathrm{g}}$, the median in-use stocks are three times higher. Yet, the average in-use stocks of $\mathrm{HH}_{\mathrm{g}}(21.3 \mathrm{~kg})$ and $\mathrm{HH}_{\mathrm{SHS}}(27.0 \mathrm{~kg})$ are within the same range. Within the cluster of SHS, the main difference between in-use stocks is the capacity of the SHS. It has two impacts: firstly it defines the weight of the SHS predominantly by the battery. Secondly, the capacity determines the possible EuPSHS to be used. The SHS with a capacity of $20 \mathrm{~W}_{\mathrm{p}}$ is the most frequently used SHS. The median capacity is $43 \mathrm{~W}_{\mathrm{p}}$, and SHSs between 40 and $50 \mathrm{~W}_{\mathrm{p}}$ stand for around $45 \%$ of the sample. Only $20 \%$ of the households possess large SHSs $\left(>50 \mathrm{~W}_{\mathrm{p}}\right.$ ) (see Supplementary S6). The higher average in-use stocks for $\mathrm{HH}_{\mathrm{SHS}}$ are caused by the internalization of the EAPs to the household's in-use stocks. From that perspective, rural electrification is not different from going off the grid in developed countries. The $2.3 \mathrm{~kW}_{\mathrm{p}}$ Smartflower pop + off-grid, "the world's first all-in-one solar system" or a first world SHS, has a product weight of $800 \mathrm{~kg}$ [90]. An average western European $\mathrm{HH}$ possesses around $650 \mathrm{~kg}$ of EEE [89], adding the $800 \mathrm{~kg}$ of an SHS would more than double the in-use stocks. Going off-the-grid as well as getting access to off-grid solutions is more material intensive on a household level than being on-grid. 


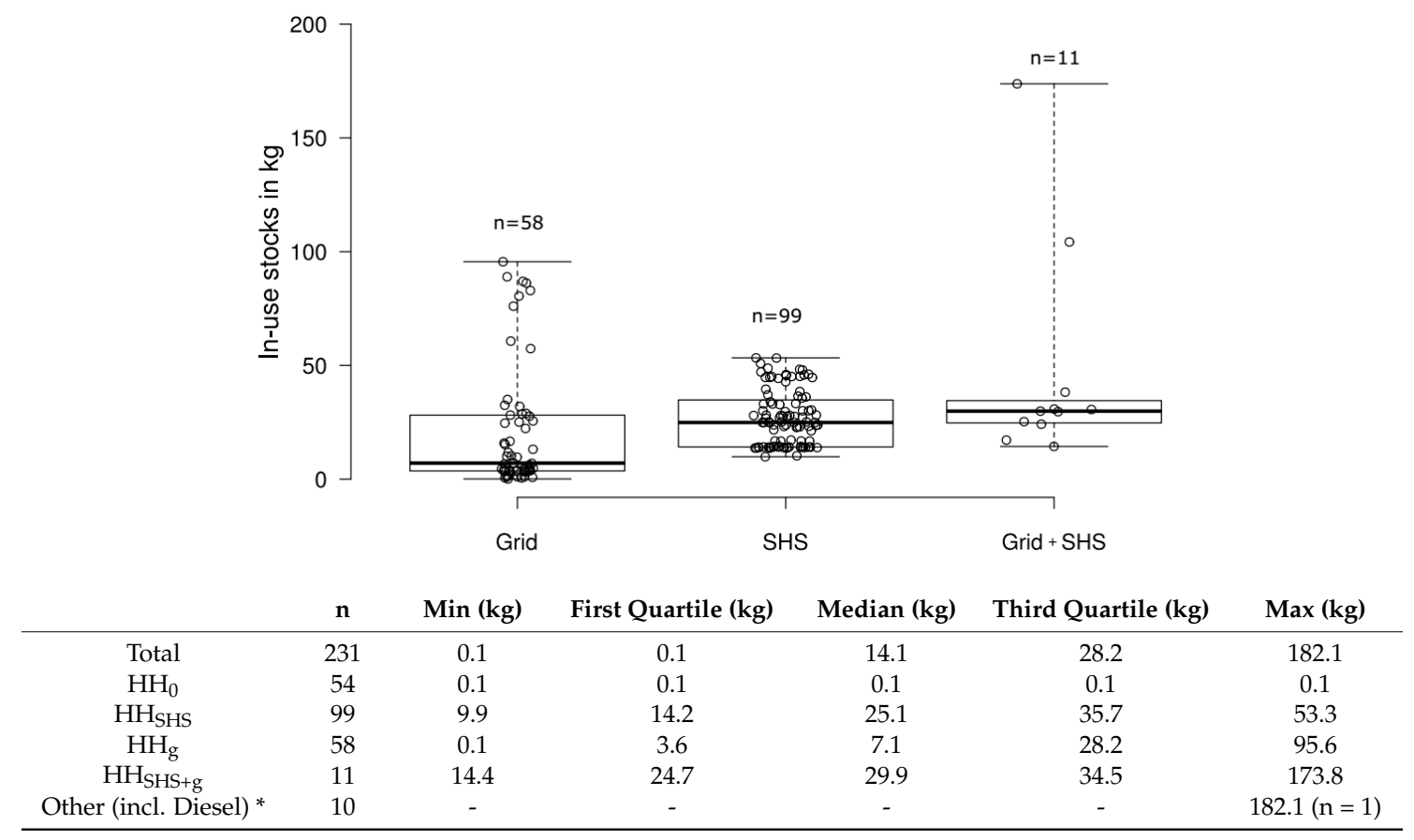

Figure 4. Box-plots of in-use stocks of electricity-using products in grid-connected households $\left(\mathrm{EuP}_{\mathrm{g}}\right)$ in $\mathrm{kg}$ of grid-connected households, in-use stocks of electricity-using products in solar home system (SHS) households (EuP $\mathrm{SHS}_{\mathrm{S}}$ ) and electricity-access products (EAPs) for households with an SHS, and households with grid connection and SHSs. The in-use stocks include all parts of the SHS.

* The household with the highest in-use stock is connected to a diesel generator.

The highest in-use stocks are found in $\mathrm{HH}_{\mathrm{SHS}+\mathrm{g}}$. Double or even triple infrastructures exist, as no source of electricity supply can fulfill all the energy needs of HHs. The grid faces power outages but offers the capacity to use high EuPs like refrigerators. The possession of an SHS guarantees lighting, TV usage, Fan usage, and mobile phone charging at any time. The HH with the highest in-use stock is connected to a diesel grid.

Additionally, the results were clustered by three types of tier status and the HHs' income (see Supplementary S8). The households with the highest in-use stocks were classified in all algorithms as Tier 1 or Tier 2. The algorithms of the MTF are sensitive to some parameters. Power outages during evening hours led directly to a Tier 1 classification. Furthermore, based on EuP ownership, a household possessing several TVs and fans, but no additional EuP cannot be classified higher than Tier 2. The appliance ownership algorithm, in this case, measures the heterogeneity of the household's access to EuPs. For household income, the results were inconsistent for the maximum values, as the highest in-use stock was found within the lowest income group (see Supplementary S8).

\subsection{Statistical Analysis of the In-Use Stocks Calculations}

\subsubsection{Analysis of the In-Use Stocks Composition}

The composition of in-use stocks was analyzed for different clusters $\left(\mathrm{HH}_{\mathrm{g}}, \mathrm{HH}_{\mathrm{SHS}}, \mathrm{HH}_{\mathrm{SHS}+\mathrm{g}}\right.$, tier status 0-3, and normalized). In all these clusters, only 3-4 EAPs or EuPs make up for around 90\% of the in-use stocks (see Table 7). Mobile phone usage is almost universal in rural communities in Bangladesh. On a weight basis, the in-use stocks of mobile phones are marginal and between $0.5 \%$ and 1.2\% (see Figure 5). 
Table 7. List of EuPs and energy access products (EAPs) determining around $90 \%$ of the in-use stocks in rural communities in Bangladesh.

\begin{tabular}{cc}
\hline Type of Access to Electricity & EuPs and EAPs \\
\hline Grid & Refrigerator, TV, Fan \\
SHS & Battery, Panel, Cables \\
SHS + Grid & Battery, TV, Fan, Panel \\
Normalized & Refrigerator, TV, Battery, Fan \\
\hline
\end{tabular}

Only $15 \%$ of the $\mathrm{HH}_{\mathrm{g}}$ possess a refrigerator. Nevertheless, refrigerators account for almost $40 \%$ of the in-use stocks of $\mathrm{HH}_{\mathrm{g}}$. Adding the in-use stocks of TVs and fans leads to the total in-use stocks of $\mathrm{EuP}_{\mathrm{g}}$ of more than $90 \%$.

Households using off-grid solar products have significantly different properties of in-use stocks than grid-connected households (see Figure 5). In the case of $\mathrm{HH}_{\mathrm{SHS}}$, more than $80 \%$ of the in-use stocks result from the EAPs. TVs and fans have a share of just $4.1 \%$ and $4.9 \%$ respectively. Newly installed SHSs will have slightly different properties, as most of the households will have TVs.

Even for $\mathrm{HH}_{\mathrm{SHS}+\mathrm{g}}$ the EAP has a share of over $50 \%$ of the in-use stocks. $\mathrm{HH}_{\mathrm{SHS}}$ qualify for at most a Tier 1 or Tier 2 status. Thus, the in-use stocks mostly consist of the SHS. In-use stocks of Tier 3 households comprise of the same three product categories that determine in-use stocks of $\mathrm{HH}_{\mathrm{g}}$ (see Figure $5 b$ ). The normalized sample for rural Bangladesh includes just $15 \%$ of $\mathrm{HH}_{\mathrm{SHS}}$, yet the battery alone contributes to $18.1 \%$ of the total in-use stocks. If all parts of the SHS are included the in-use stocks contribute to $23 \%$. Just $8 \%$ of the households in the normalized case possess a refrigerator; nevertheless, it results in a $28.7 \%$ share of the in-use stocks (see Figure $5 \mathrm{c}$ ).

\subsubsection{Sensitivity Analysis of the Results}

The change in the possession of EuPs in rural Bangladesh is highly dynamic (see Table 5). It took just a decade for rural households to achieve almost universal access to mobile phones. Additionally, from 2007 to 2014, the possession of refrigerators doubled three times and grew from $2.5 \%$ to $12.3 \%$ in rural Bangladesh. If it doubles just twice within the next seven years, $50 \%$ of the $\mathrm{HH}_{\mathrm{g}}$ will possess a refrigerator. In that case, the in-use stocks for the normalized sample $\mathrm{HH}$ would grow by $66.9 \%$ (see Table 8). The diffusion rate of SHS is highly dynamic. Within 10 years the percentage of rural $\mathrm{HH}$ using solar products as their primary energy source rose from 0 to $15 \%$.

Table 8. Sensitivity analysis of the total in-use stocks of EuPs and EAPs for grid-connected households $\left(\mathrm{HH}_{\mathrm{g}}\right)$, solar home system households $\left(\mathrm{HH}_{\mathrm{SHS}}\right)$, and normalized households $(\mathrm{HH})$.

\begin{tabular}{cccc}
\hline Scenario & $\mathbf{H H}_{\mathbf{g}}$ & $\mathbf{H H}_{\mathbf{S H S}}$ & Normalized HH \\
\hline Excluding the biggest factor $\mathrm{HH}_{\mathrm{g}}$ (refrigerator) & $-39.5 \%$ & - & $-28.7 \%$ \\
Excluding the biggest factor $\mathrm{HH}_{\mathrm{SHS}}$ (lead acid-battery) & - & $-66.7 \%$ & $-18.1 \%$ \\
$+10 \%$ biggest factor & $3.9 \%$ & $6.7 \%$ & $2.9 \%$ \\
$+50 \%$ biggest factor & $19.7 \%$ & $33.4 \%$ & $14.3 \%$ \\
$50 \%$ possession of refrigerators in $\mathrm{HH}_{\mathrm{g}}$ & $92.1 \%$ & - & $66.9 \%$ \\
$50 \%$ possession of $\mathrm{TV}$ in $\mathrm{HH}$ SHS & - & $13.5 \%$ & $3.5 \%$ \\
Excluding the top 10\% of HH & $-41.5 \%$ & $-8.2 \%$ & - \\
Excluding the top 25\% of HH & $-59.4 \%$ & $-21.3 \%$ & - \\
Excluding the minimum 10\% of $\mathrm{HH}$ & $10.9 \%$ & $5.1 \%$ & - \\
Excluding the minimum $25 \%$ of $\mathrm{HH}$ & $26.9 \%$ & $15.7 \%$ & - \\
Including (SHS + Grid) into $\mathrm{HH}$ and $\mathrm{HH} \mathrm{H}_{\mathrm{SHS}}$ & $19.2 \%$ & $7.3 \%$ & $15.9 \%$ \\
\hline
\end{tabular}




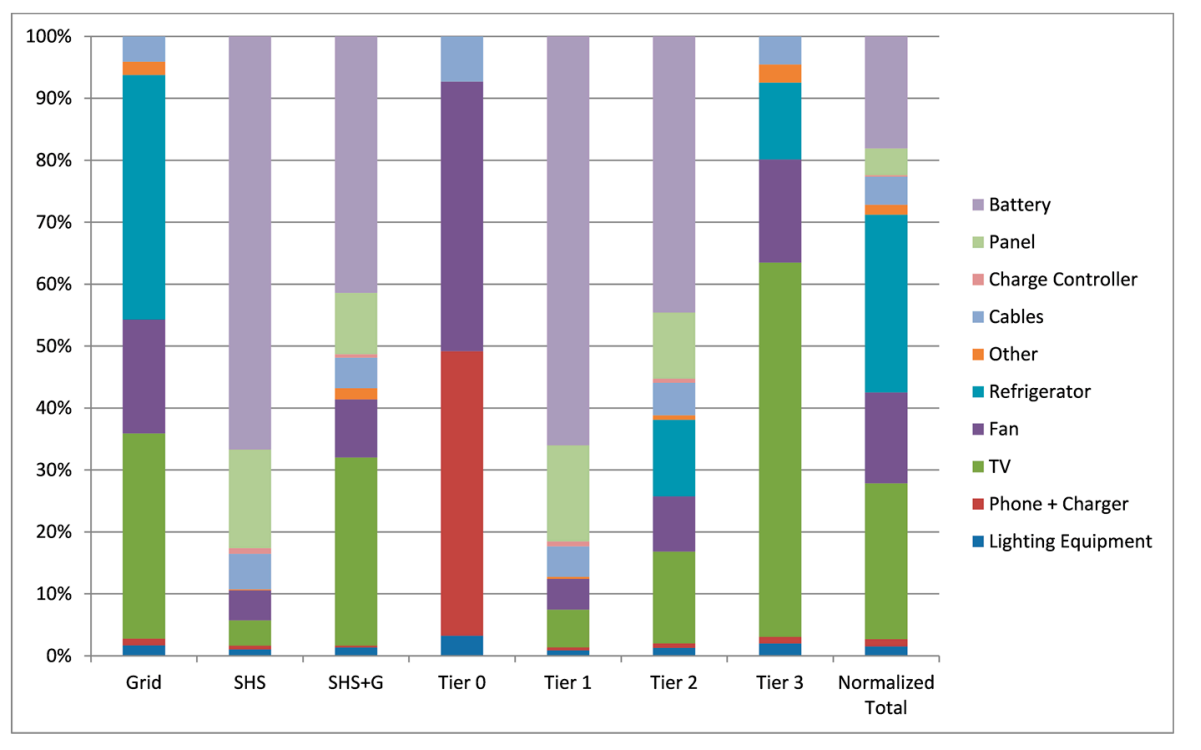

(a)

\begin{tabular}{|c|c|c|c|c|c|c|c|c|c|c|c|}
\hline & $\begin{array}{c}\text { Average In-Use Stock of EEE } \\
\text { Per HH (kg) }\end{array}$ & $\begin{array}{l}\text { Lighting } \\
\text { Equipment }\end{array}$ & $\begin{array}{l}\text { Phone + } \\
\text { Charger }\end{array}$ & TV & Fan & Fridge & Other & Cables & Charge Controller & Panel & Battery \\
\hline $\mathrm{HH}_{\mathrm{g}}$ & 21.3 & $1.7 \%$ & $1.1 \%$ & $33.1 \%$ & $18.4 \%$ & $39.5 \%$ & $2.1 \%$ & $4.1 \%$ & $0.0 \%$ & $0.0 \%$ & $0.0 \%$ \\
\hline HHshs & 27.0 & $1.0 \%$ & $0.6 \%$ & $4.1 \%$ & $4.9 \%$ & $0.0 \%$ & $0.2 \%$ & $5.7 \%$ & $0.9 \%$ & $15.9 \%$ & $66.7 \%$ \\
\hline HHsHS+g & 47.1 & $1.3 \%$ & $0.3 \%$ & $30.4 \%$ & $9.4 \%$ & $0.0 \%$ & $1.8 \%$ & $4.9 \%$ & $0.6 \%$ & $9.9 \%$ & $41.4 \%$ \\
\hline Tier 0 & 0.2 & $3.2 \%$ & $45.9 \%$ & $0.0 \%$ & $43.5 \%$ & $0.0 \%$ & $0.0 \%$ & $7.3 \%$ & $0.0 \%$ & $0.0 \%$ & $0.0 \%$ \\
\hline Tier 1 & 29.8 & $0.9 \%$ & $0.5 \%$ & $6.1 \%$ & $4.9 \%$ & $0.0 \%$ & $0.3 \%$ & $4.9 \%$ & $0.8 \%$ & $15.5 \%$ & $66.0 \%$ \\
\hline Tier 2 & 26.0 & $1.3 \%$ & $0.7 \%$ & $14.8 \%$ & $8.9 \%$ & $12.3 \%$ & $0.7 \%$ & $5.3 \%$ & $0.6 \%$ & $10.7 \%$ & $44.6 \%$ \\
\hline Tier 3 & 25.7 & $2.0 \%$ & $1.0 \%$ & $60.4 \%$ & $16.7 \%$ & $12.4 \%$ & $2.9 \%$ & $4.5 \%$ & $0.0 \%$ & $0.0 \%$ & $0.0 \%$ \\
\hline $\begin{array}{l}\text { Normalized } \\
\text { Total }\end{array}$ & 14.9 & $1.5 \%$ & $1.2 \%$ & $25.2 \%$ & $14.7 \%$ & $28.7 \%$ & $1.6 \%$ & $4.5 \%$ & $0.3 \%$ & $4.3 \%$ & $18.1 \%$ \\
\hline
\end{tabular}

(c)

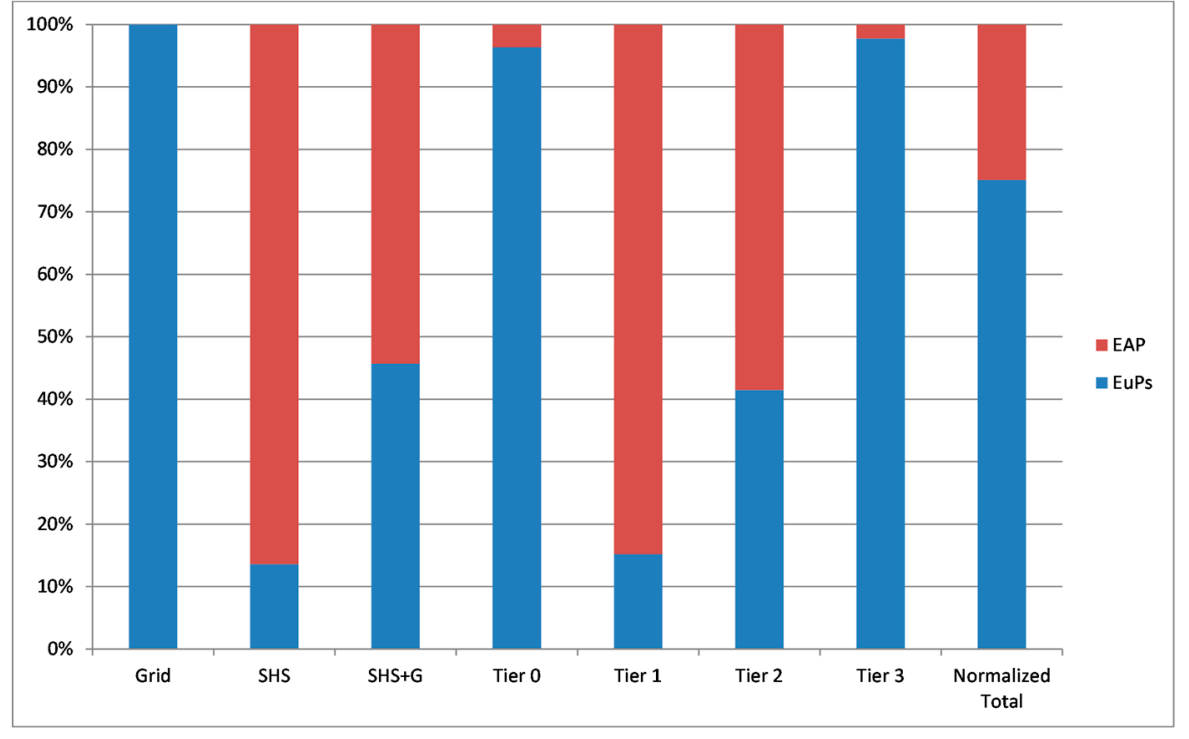

(b)

Figure 5. (a) Percentage of EAPs and EuPs in in-use stocks of different clusters (Grid, SHS; SHS+G, Tier Status, Normalized Total); (b) Summarized percentage of EuPs and EAP in in-use stocks of different clusters (Grid, SHS, SHS + G, Tier Status, Normalized Total); (c) Table with the percentages of the in-use stocks in different clusters. All EuPs with a share lower than $5 \%$ were grouped into the "Other" category. The "Other" category varies between the different clusters. 
Excluding the single biggest $\mathrm{EuP}_{\mathrm{g}}$ from the $\mathrm{HH}_{\mathrm{g}}$ lowers even the normalized average by $28.7 \%$. Excluding the lead-acid batteries changes the normalized results by $18.1 \%$ and for $\mathrm{HH}_{\mathrm{SHS}}$ by $66.7 \%$. Thus, for estimating in-use stocks of $\mathrm{HH}_{\mathrm{SHS}}$, the battery technology is by far the most important parameter. In the scenario where half of the $\mathrm{HH}_{\mathrm{g}}$ possess a refrigerator, the total in-use stocks nearly doubles and even the normalized in-use stocks would grow by two-thirds. Furthermore, especially for $\mathrm{HH}_{\mathrm{g}}$, the in-use stocks of the top $25 \%$ of households should be analyzed, as they nearly possess $60 \%$ of the total in-use stocks.

\section{Discussion}

\subsection{Dimension of the SHS Program for Stocks and Flows of EEE in Bangladesh}

Within the sample, the average in-use stock of $\mathrm{HH}_{\mathrm{SHS}}$ is $27.0 \mathrm{~kg}(\mathrm{SD}=12.0 \mathrm{~kg}$, see Figure 5). The 4 million SHSs in Bangladesh by the end of 2016 result in a total in-use stock of SHS of $108 \mathrm{Gg}$ (SD = $48 \mathrm{Gg}$ ). To achieve the goal of 6 million SHSs by 2021, 500,000 SHSs have to be installed annually, resulting in an annual addition to the stock by $13.5 \mathrm{Gg}(\mathrm{SD}=6 \mathrm{Gg})$. In 2012, it was estimated that $208 \mathrm{Gg}$ of EEE was put on the market or $1.4 \mathrm{~kg}$ per capita [91]. On a weight basis, the SHS program already adds around $6 \%$ to this number. Thus, the SHS program of Bangladesh already has a measurable impact on the EEE market, if off-grid solar products are categorized as EEE. Furthermore, the material flows in Bangladesh, a country with the highest diffusion rate of SHS in the world, are significantly higher than for the 14 Energy Africa countries [29]. Similar findings are to be expected in all countries, where significant shares of access to electricity are provided by SHSs.

\subsection{Waste Categorization for Off-Grid Solar Products}

Most off-grid solar products are developed for the SHS ecosystem and have limitations in the given context [63]. Distributors provide for example LEDs integrated into the lampshade connected to the cable. By function, they should be categorized into the lamps category. Charge controllers are difficult to classify because in function they are similar to converters. For small SHSs it is even more complicated, as charge controllers are integrated into the batteries-mostly lithium-ion or lithium iron phosphate batteries-and referred to as "control boxes". A control box could be classified as an external battery. Nowadays, in the SHS program of Bangladesh, external lead-acid batteries are universally used. As long as there is no change in the technology, the batteries for the SHS program would be in the hazardous waste category. PV panels are categorized as large equipment, which is not the right category for panels for small and medium SHSs.

\subsection{The Owner Perspective of Nonfunctional EuPSHS and EAPS as E-Waste}

Owners of nonfunctional EuPs and EAPS in the given context have a preference for repairing, replacing or selling nonfunctional appliances. If a component of the SHS fails, the household loses its access to electricity. As most SHSs are distributed on microcredits, nonfunctional systems result in a credit risk for the distributor. Thus, both owner and distributor have an incentive to replace, repair, and reuse, leading to comparatively long lifespans of off-grid solar products. Evidence for the most valuable part, the lead-acid batteries, is available in rural Bangladesh. Over $90 \%$ of warranty-expired batteries have not been changed during the warranty period. The formal warranty scheme of the Bangladeshi SHS program offers a $24 \%$ discount on a new battery if the old one is handed in [92]. Of the batteries being changed, the informal sector has a market share of around 50\% [93]. Thus, some SHS owners are experienced in selling nonfunctional EAPs to the informal sector. Yet, there is no information available regarding the charge controllers, PV panels, wiring, or other EuPSHS. Similar preferences can be assumed, as it either guarantees the functionality of the SHS or results in revenues for the households. Contrary to the definition of e-waste, nonfunctional off-grid solar products or EEE in the given context are most likely not discarded as waste by the owners. 


\subsection{Limitations of the Research and the Methodology}

The importance of the type of access to electricity for in-use stocks of EEE in rural communities with access to electricity deficits was highlighted. The used dataset was not representative for rural Bangladesh as a whole, as the selected areas have a lower access-to-electricity rate than average rural Bangladesh. Results based on the used dataset for the normalized household underestimates the in-use stocks for rural Bangladesh, as the possession of large household appliances is lower than the average from the DHS studies. Furthermore, in the total dataset, SHSs were overrepresented. The share of the in-use stocks in Tier 1 and Tier 2 grouped households is dominated by SHSs, as SHSs cannot be classified higher than Tier 2. This leads to a slightly declining average of in-use stocks with higher tier statuses (see Figure 5). This may not be the case for datasets with lower shares of SHSs.

\section{Conclusions and Outlook}

The presented methodology allows an assessment of in-use stocks for off-grid solar products and EEE for rural communities in developing countries based on energy access data. The impact of the type of access-to-electricity was highlighted by clustering and statistically analyzing the in-use stocks. A share of just $15 \%$ of households using SHS results on a weight basis in $23 \%$ of the total in-use stocks. Even though, the average weights of off-grid solar products are significantly lower than for regular EuPs and EEE.

More than $90 \%$ of the in-use stocks of the different clusters can be assigned to four EuPs or EAPs. If the grid is extended, the waste management challenges remain the same and should focus on refrigerators, TVs, and fans. If significant shares of distributed renewable energies are planned, households use different EuPs and possess additionally comparatively heavy EAPs at home. Within the cluster of $\mathrm{HH}_{\mathrm{SHS}}$ the capacity of the SHS is the main factor to determine in-use stocks.

Future research regarding off-grid electrification could focus on the estimation of material stocks being required for universal access to electricity depending on different access to electricity strategies. Furthermore, the impact of the business model used to distribute off-grid solar products or EEE could be studied. Additionally, environmental impacts of different types of access to electricity could be analyzed. Last but not least, the user perspective on nonfunctional off-grid solar products and EEE could be studied.

Supplementary Materials: The following are available online at www.mdpi.com/2313-4321/3/1/7/s1. S1: Selection of SHS bundles distributed by Grameen Shakti in Bangladesh in 2016; S2: Verbal Description of the Attribution of Tier Status (Supply Simple 2015); S3: Tier Status of Households; S4: Physical Properties of Solar Off-Grid Products: Raw Data of the Market Research; S5: Linear Regression of the Weight of Pv Panels and Lead-Acid Batteries over Capacity. S6: Distribution of SHS Capacity within the Surveyed Sample; S7: Modelling Assumptions and used Literature Values; S8: Statistical Distribution of the In-use Stocks by Different Clusters; S9: Questionnaire of the Access to Electricity Survey.

Acknowledgments: This research is part of the Ph.D. project "Rural Electrification and (E-)Waste" of Alexander Batteiger. His research is funded by a scholarship from the Hans-Böckler Foundation. Data from a survey for access to electricity was gratefully provided by Sebastian Groh, a colleague at the microenergy systems research group at Technische Universität, Berlin. Furthermore, the authors would like to thank the internal reviewers from the microenergy research group and the chair of circular economy and recycling technologies at Technische Universität, Berlin. Last but not least, the authors would like to thank the reviewers for their valuable critique and input.

Author Contributions: Alexander Batteiger and Susanne Rotter designed the research framework. Alexander Batteiger conducted the research and wrote the paper. Susanne Rotter has taken part in conceptualizing the research work, reviewing, and checking the paper structure and content.

Conflicts of Interest: The authors declare no conflicts of interest. 


\section{Abbreviation}

\begin{tabular}{|c|c|}
\hline EAP & Energy Access Product \\
\hline EEE & Electrical and Electronic Equipment \\
\hline ESMAP & Energy Sector Management Assistance Program (World Bank) \\
\hline $\mathrm{EuP}$ & Electricity-using Product \\
\hline $\mathrm{EUP}_{\mathrm{g}}$ & Electricity-using Product, found in a grid-connected household \\
\hline EUP $_{\text {SHS }}$ & Electricity-using Product found in a Solar Home System household \\
\hline GDP & Gross Domestic Product \\
\hline $\mathrm{HH}$ & Household \\
\hline $\mathrm{HH}_{\mathrm{g}}$ & Household having grid connection \\
\hline $\mathrm{HH}_{\mathrm{O}}$ & Household not having access to electricity \\
\hline $\mathrm{HH}_{\mathrm{SHS}}$ & Household possessing a Solar Home System \\
\hline $\mathrm{HH}_{\mathrm{SHS}+\mathrm{g}}$ & Household having grid connection and a Solar Home System \\
\hline IEAG & Independent Expert Advisory Group on a Data Revolution for Sustainable Development \\
\hline LCD & Liquid Cristal Diode \\
\hline LED & Light Emitting Diode \\
\hline MDG & Millennium Development Goal \\
\hline MFA & Material Flow Analysis \\
\hline MTF & Multitier Framework \\
\hline PV & Photovoltaic \\
\hline SDG & Sustainable Development Goal \\
\hline SHS & Solar Home System \\
\hline STEP & Solving the E-waste Problem Initiative \\
\hline UNEP & United Nations Environment Programme \\
\hline UNU & United Nations University \\
\hline WEEE & Waste Electrical and Electronic Equipment \\
\hline
\end{tabular}

\section{References}

1. Thomas Edison Rutgers School of Arts and Sciences. Available online: http:/ / edison.rutgers.edu/latimer/ tae1.htm (accessed on 13 October 2016).

2. World Bank. World Bank Global Tracking Framework 2017: Progress Towards Sustainable Energy; World Bank: Washington, DC, USA, 2017.

3. Ki-moon, B. Our Vision I Sustainable Energy for All (SEforALL). Available online: http://se4all.org/ourvision (accessed on 13 October 2016).

4. United Nations Economic and Social Council. Progress towards the Sustainable Development Goals; UN Report of the Secretary-General; E/2016/75; United Nations Economic and Social Council: New York, NY, USA, 2016.

5. Bensch, G.; Peters, J.; Sievert, M. The lighting transition in rural Africa-From kerosene to battery-powered LED and the emerging disposal problem. Energy Sustain. Dev. 2017, 39, 13-20. [CrossRef]

6. Mills, E.; Tracy, J.L.; Alstone, P.; Jacobson, A.; Avato, P. Low-cost LED flashlights and market spoiling in Kenya's off-grid lighting market. Energy Effic. 2014, 1-15. [CrossRef]

7. Bazilian, M.; Nussbaumer, P.; Rogner, H.-H.; Brew-Hammond, A.; Foster, V.; Pachauri, S.; Williams, E.; Howells, M.; Niyongabo, P.; Musaba, L.; et al. Energy access scenarios to 2030 for the power sector in sub-Saharan Africa. Util. Policy 2012, 20, 1-16. [CrossRef]

8. International Energy Agency. IEA World Energy Outlook 2016; International Energy Agency: Paris, France, 2016.

9. Organisation for Economic Co-operation and Development (OECD)//IEA. Enery for All. Financing Access for the Poor. Special Early Excerpt of the World Energy Outlook 2011; OECD/IEA: Paris, France, 2011.

10. Pachauri, S.; van Ruijven, B.J.; Nagai, Y.; Riahi, K.; van Vuuren, D.P.; Brew-Hammond, A.; Nakicenovic, N. Pathways to achieve universal household access to modern energy by 2030. Environ. Res. Lett. 2013, 8, 024015. [CrossRef]

11. Palit, D. Solar energy programs for rural electrification: Experiences and lessons from South Asia. Energy Sustain. Dev. 2013, 17, 270-279. [CrossRef] 
12. Sadeque, Z.; Rysankova, D.; Elahi, R.; Soni, R. Scaling Up Access to Electricity: The Case of Bangladesh; Live Wire 2014; World Bank: Washington, DC, USA, 2014.

13. Global Leap. The State of the Off-Grid Appliance Market; U.S. Department of Energy-Global Lighting and Energy Access Partnership (Global LEAP): Washington, DC, USA, 2016.

14. Feron, S. Sustainability of Off-Grid Photovoltaic Systems for Rural Electrification in Developing Countries: A Review. Sustainability 2016, 8, 1326. [CrossRef]

15. REN21 Secretariat. Renewables 2016 Global Status Report; REN21 Secretariat: Paris, France, 2016.

16. Sovacool, B.K.; Bazilian, M.; Toman, M. Paradigms and poverty in global energy policy: Research needs for achieving universal energy access. Environ. Res. Lett. 2016, 11, 064014. [CrossRef]

17. Herat, S.; Agamuthu, P. E-waste: A problem or an opportunity? Review of issues, challenges and solutions in Asian countries. Waste Manag. Res. 2012, 30, 1113-1129. [CrossRef] [PubMed]

18. European Parliament and the Council of the European Union. Proceedings of the Directive 2012/19/EU of the European Parliament and of the council of 4 July 2012 on Waste Electrical and Electronic Equipment (WEEE), Brussels, Belgium, 2012.

19. Graedel, T.E. Metal Stocks in Society—Scientific Synthesis; UNEP: New York, NY, USA, 2010.

20. Schluep, M.; Müller, E.; Hilty, L.; Ott, D.; Widmer, R.; Böni, H. Insights from a decade of development cooperation in e-waste management. In Proceedings of the ICT4S-First International Conference on Information and Communication Technologies for Sustainability, Zürich, Switzerland, 12-14 February 2013; pp. 223-230. [CrossRef]

21. ESMAP, Beyond Connections Energy Access Redefined, 2015. Available online: http://www.sun-connectnews.org/fileadmin/DATEIEN/Dateien/New / Beyond_Connections_Energy_Access_Redefined_Exec_ ESMAP_2015.pdf (accessed on 22 July 2015).

22. United Nations Secretary-General's Independent Expert Advisory Group on a Data Revolution for Sustainable Development. A World That Counts-Mobilising the Data Revolution for Sustainable Development. Available online: http://www.undatarevolution.org/wp-content/uploads/2014/12/AWorld-That-Counts2.pdf (accessed on 12 December 2017).

23. Groh, S.; Pachauri, S.; Narasimha, R. What are we measuring? An empirical analysis of household electricity access metrics in rural Bangladesh. Energy Sustain. Dev. 2016, 30, 21-31. [CrossRef]

24. Jain, A.; Ray, S.; Ganesan, K.; Aklin, M.; Cheng, C.-Y.; Urpelainen, J. Access to Clean Cooking Energy and Electricity-Survey of States-CEEW ACCESS Report September 2015; Council on Energy, Environment and Water: New Delhi, India, 2015.

25. Lighting Global. Eco Design Notes. Available online: https://www.lightingglobal.org/resources/ecodesign-notes / (accessed on 20 November 2016).

26. GOGLA (Global Off-Grid Lighting Assosciation). Gogla Industry Opinion on Lifecycle and Recycling. Available online: http://global-off-grid-lighting-association.org/sites/www.gogla.org/files/recource_ docs/gogla-industry-opinion-on-lifecycle-and-recycling1.pdf (accessed on 20 September 2016).

27. Schützeichel, H. No Grid-No Problem. Available online: http://sun-connect-news.org/fileadmin/ DATEIEN/Dateien/New / No-grid-no-problem_onlineversion.pdf (accessed on 20 September 2016).

28. GOGLA. Lighting Global Conference Report-4th International Off-Grid Lighting Conference and Exhibition. In Proceedings of the 4th International Off-Grid Lighting Conference and Exhibition, Dubai, UAE, 26-29 October 2015.

29. Magalini, F.; Sinha-Khetriwal, D.; Rochat, D.; Huismann, J.; Munyambu, S.; Oliech, J.; Chidiabsu, I.; Mbera, O. Electronic Waste (e-Waste) Impacts and Mitigation Options in the Off-Grid Renewable Energy Sector; Evidence on Demand: London, UK, 2016.

30. Balde, C.P.; Kuehr, R.; Blumenthal, K.; Gill, S.F.; Kern, M.; Micheli, P.; Magpantay, E.; Huisman, J. E-Waste Statistics: Guidelines on Classifications, Reporting and Indicators; United Nations University: Bonn, Germany, 2015; ISBN 978-92-8-084554-9.

31. STEP. Solving the E-Waste Problem Initiative, One Global Definition of E-Waste. Available online: http:/ / www.step-initiative.org/files/step/_documents/StEP_WP_One\%20Global\%20Definition\%20of\% 20E-waste_20140603_amended.pdf (accessed on 10 March 2017).

32. Wang, F.; Huisman, J.; Baldé, K.; Stevels, A. A systematic and compatible classification of WEEE. In Proceedings of the 2012 Electronics Goes Green 2012+, Berlin, Germany, 9-12 September 2012; pp. 1-6. 
33. UNEP. Call for Global Action on E-waste-United Nations Environment Programme (UNEP). Available online: http:/ / www.unep.org/Documents.Multilingual/Default.asp?ArticleID=5447\&DocumentID=496\&l=en (accessed on 23 November 2016).

34. Robinson, B.H. E-waste: An assessment of global production and environmental impacts. Sci. Total Environ. 2009, 408, 183-191. [CrossRef] [PubMed]

35. Baldé, C.P.; Wang, F.; Kuehr, R.; Huisman, J. The Global e-Waste Monitor-2014; United Nations University, IAS-SCYCLE: Bonn, Germany, 2015.

36. Cucchiella, F.; D'Adamo, I.; Lenny Koh, S.C.; Rosa, P. Recycling of WEEEs: An economic assessment of present and future e-waste streams. Renew. Sustain. Energy Rev. 2015, 51, 263-272. [CrossRef]

37. Liu, W.; Chen, L.; Tian, J. Uncovering the Evolution of Lead In-Use Stocks in Lead-Acid Batteries and the Impact on Future Lead Metabolism in China. Environ. Sci. Technol. 2016, 50, 5412-5419. [CrossRef] [PubMed]

38. IRENA and IEA-PVPS. End-of-Life Management: Solar Photovoltaic Panels; International Renewable Energy Agency: Abu Dhabi, UAE; International Energy Agency Photovoltaic Power Systems: St. Ursen, Switzerland, 2016.

39. Ongondo, F.O.; Williams, I.D.; Cherrett, T.J. How are WEEE doing? A global review of the management of electrical and electronic wastes. Waste Manag. 2011, 31, 714-730. [CrossRef] [PubMed]

40. Widmer, R.; Oswald-Krapf, H.; Sinha-Khetriwal, D.; Schnellmann, M.; Böni, H. Global perspectives on e-waste. Environ. Impact Assess. Rev. 2005, 25, 436-458. [CrossRef]

41. Hamouda, K.; Adjroudi, R.; Rotter, V.S.; Wang, F. Methodology for WEEE assessment in Algeria. Int. J. Environ. Stud. 2017, 74, 568-585. [CrossRef]

42. Sepúlveda, A.; Schluep, M.; Renaud, F.G.; Streicher, M.; Kuehr, R.; Hagelüken, C.; Gerecke, A.C. A review of the environmental fate and effects of hazardous substances released from electrical and electronic equipments during recycling: Examples from China and India. Environ. Impact Assess. Rev. 2010, 30, 28-41. [CrossRef]

43. Heacock, M.; Kelly, C.B.; Asante, K.A.; Birnbaum, L.S.; Bergman, Å.L.; Bruné, M.-N.; Buka, I.; Carpenter, D.O.; Chen, A.; Huo, X.; et al. E-Waste and Harm to Vulnerable Populations: A Growing Global Problem. Environ. Health Perspect. 2016, 124, 550-555. [CrossRef] [PubMed]

44. Graedel, T.E.; Allwood, J.; Birat, J.-P.; Buchert, M.; Hagelüken, C.; Reck, B.K.; Sibley, S.F.; Sonnemann, G. What Do We Know About Metal Recycling Rates? J. Ind. Ecol. 2011, 15, 355-366. [CrossRef]

45. Wang, F.; Huisman, J.; Stevels, A.; Balde, C.P. Enhancing e-waste estimates: Improving data quality by multivariate Input-Output Analysis. Waste Manag. 2013, 33, 2397-2407. [CrossRef] [PubMed]

46. Araújo, M.G.; Magrini, A.; Mahler, C.F.; Bilitewski, B. A model for estimation of potential generation of waste electrical and electronic equipment in Brazil. Waste Manag. 2012, 32, 335-342. [CrossRef] [PubMed]

47. Oguchi, M.; Kameya, T.; Yagi, S.; Urano, K. Product flow analysis of various consumer durables in Japan. Resour. Conserv. Recycl. 2008, 52, 463-480. [CrossRef]

48. Yu, J.; Williams, E.; Ju, M.; Yang, Y. Forecasting Global Generation of Obsolete Personal Computers. Environ. Sci. Technol. 2010, 44, 3232-3237. [CrossRef] [PubMed]

49. Kumar, A.; Holuszko, M.; Espinosa, D.C.R. E-waste: An overview on generation, collection, legislation and recycling practices. Resour. Conserv. Recycl. 2017, 122, 32-42. [CrossRef]

50. Oguchi, M.; Terazono, A.; Masaaki, F. Future Generation of WEEE in Developing Countries: An Estimation Model and Case Studies in Asia. In Proceedings of the Electronic Goes Green 2016+; Technische Universität Berlin: Berlin, Germany, 2016.

51. Kahhat, R.; Williams, E. Materials flow analysis of e-waste: Domestic flows and exports of used computers from the United States. Resour. Conserv. Recycl. 2012, 67, 67-74. [CrossRef]

52. Steubing, B.; Böni, H.; Schluep, M.; Silva, U.; Ludwig, C. Assessing computer waste generation in Chile using material flow analysis. Waste Manag. 2010, 30, 473-482. [CrossRef] [PubMed]

53. Andarani, P.; Goto, N. Potential e-waste generated from households in Indonesia using material flow analysis. J. Mater. Cycles Waste Manag. 2013, 16, 306-320. [CrossRef]

54. Streicher-Porte, M.; Bader, H.-P.; Scheidegger, R.; Kytzia, S. Material flow and economic analysis as a suitable tool for system analysis under the constraints of poor data availability and quality in emerging economies. Clean Technol. Environ. Policy 2007, 9, 325-345. [CrossRef]

55. Chancerel, P.; Rotter, S. Recycling-oriented characterization of small waste electrical and electronic equipment. Waste Manag. 2009, 29, 2336-2352. [CrossRef] [PubMed]

56. Lam, C.W.; Lim, S.-R.; Schoenung, J.M. Linking Material Flow Analysis with Environmental Impact Potential. J. Ind. Ecol. 2013, 17, 299-309. [CrossRef] 
57. Agamuthu, P.; Kasapo, P.; Mohd Nordin, N.A. E-waste flow among selected institutions of higher learning using material flow analysis model. Resour. Conserv. Recycl. 2015, 105 Pt A, 177-185. [CrossRef]

58. Lau, W.K.-Y.; Chung, S.-S.; Zhang, C. A material flow analysis on current electrical and electronic waste disposal from Hong Kong households. Waste Manag. 2013, 33, 714-721. [CrossRef] [PubMed]

59. Mishima, K.; Rosano, M.; Mishima, N.; Nishimura, H. End-of-Life Strategies for Used Mobile Phones Using Material Flow Modeling. Recycling 2016, 1, 122. [CrossRef]

60. Schillebeeckx, S.J.D.; Parikh, P.; Bansal, R.; George, G. An integrated framework for rural electrification: Adopting a user-centric approach to business model development. Energy Policy 2012, 48, 687-697. [CrossRef]

61. Durlinger, B.; Reinders, A.; Toxopeus, M. A comparative life cycle analysis of low power PV lighting products for rural areas in South East Asia. Renew. Energy 2012, 41, 96-104. [CrossRef]

62. Alstone, P.; Lai, P.; Mills, E.; Jacobson, A. High Life Cycle Efficacy Explains Fast Energy Payback for Improved Off-Grid Lighting Systems. J. Ind. Ecol. 2014, 18, 722-733. [CrossRef]

63. Stojanovski, O.; Thurber, M.; Wolak, F. Rural energy access through solar home systems: Use patterns and opportunities for improvement. Energy Sustain. Dev. 2017, 37, 33-50. [CrossRef]

64. Emili, S.; Ceschin, F.; Harrison, D. Product-Service System applied to Distributed Renewable Energy: A classification system, 15 archetypal models and a strategic design tool. Energy Sustain. Dev. 2016, 32, 71-98. [CrossRef]

65. Batteiger, A. Off-Grid Electrification and its Impacts on the Waste Management System-The Case of Bangladesh. Available online: http:/ / www.ucl.ac.uk/steapp/isngi/proceedings (accessed on 1 February 2016).

66. IRENA (International Renewable Energy Agency). Renewable Energy and Jobs-Annual Review 2016. Available online: http:/ / www.irena.org/rejobs.pdf (accessed on 23 March 2016).

67. Alstone, P.; Gershenson, D.; Kammen, D.M. Decentralized energy systems for clean electricity access. Nat. Clim. Chang. 2015, 5, 305-314. [CrossRef]

68. IDCOL (Infrastructure and Development Company Limited). Dhaka. Bangladesh. Available online: http:/ / www.idcol.org/old/bd-map/bangladesh_map/ (accessed on 6 August 2016).

69. IRENA. Renewable Capacity Statistics 2017; International Renewable Energy Agency: Abu Dhabi, UAE, 2017.

70. National Institute of Population Research and Training (NIPORT); Mitra and Associates; ICF International. Bangladesh Demographic and Health Survey 2014; NIPORT: Dhaka, Bangladesh; Mitra and Associates: Dhaka, Bangladesh; ICF International: Rockville, MD, USA, 2016.

71. IDCOL. IDCOL SHS Installation under RE Program. Available online: http://www.webcitation.org/ 6qS3DqlMD (accessed on 14 May 2017).

72. World Bank Database. Available online: http:/ / data.worldbank.org (accessed on 13 March 2017).

73. Department of Environment. National 3R-Strategy for Waste Management 2010; Department of Environment: Dhaka, Bangladesh, 2010.

74. IDCOL. Infrastructure and Development Company Limited. Rural Electrification and Renewable Energy Development Project II-Updated Environmental and Social Management Framework 2014. Available online: http:/ /idcol.org/download/e26ae795489e5b7351aed40e044553a2.pdf (accessed on 18 August 2015).

75. Environment and Social Development Organization (ESDO). Magnitude of the Flow of E-waste in Bangladesh, Dhaka, Bangladesh, 2016.

76. Lepawsky, J.; Billah, M. Making Chains That (un)make Things: Waste-Value Relations and the Bangladeshi Rubbish Electronics Industry. Geogr. Ann. Ser. B Hum. Geogr. 2011, 93, 121-139. [CrossRef]

77. Lepawsky, J.; Connolly, C. A crack in the facade? Situating Singapore in global flows of electronic waste. Singap. J. Trop. Geogr. 2016, 37, 158-175. [CrossRef]

78. Alam, M.; Bahauddin, K.M. E-Waste In Bangladesh: Evaluating The Situation, Legislation And Policy And Way Forward With Strategy And Approach. Present Environ. Sustain. Dev. 2015, 9, 25-46. [CrossRef]

79. Sthiannopkao, S.; Wong, M.H. Handling e-waste in developed and developing countries: Initiatives, practices, and consequences. Sci. Total Environ. 2013, 463-464, 1147-1153. [CrossRef] [PubMed]

80. Ahmed, S. Measuring the Willingness to Pay for Hazard-Free e-Waste Management in Dhaka city, Bangladesh. Available online: http:/ / www.eldis.org/go/topics\&id=61003\&type=Document\#.WMBeS_ ItKkQ (accessed on 8 March 2017). 
81. Islam, M.T.; Abdullah, A.B.; Shahir, S.A.; Kalam, M.A.; Masjuki, H.H.; Shumon, R.; Rashid, M.H. A public survey on knowledge, awareness, attitude and willingness to pay for WEEE management: Case study in Bangladesh. J. Clean. Prod. 2016, 137, 728-740. [CrossRef]

82. National Institute of Population Research and Training (NIPORT); Mitra and Associates; ORC Macro. Bangladesh Demographic and Health Survey 2011; National Institute of Population Research and Training: Dhaka, Bangladesh; Mitra and Associates: Dhaka, Bangladesh; ORC Macro: Calverton, MD, USA, 2013.

83. National Institute of Population Research and Training (NIPORT); Mitra and Associates; ORC Macro. Bangladesh Demographic and Health Survey 2007; National Institute of Population Research and Training: Dhaka, Bangladesh; Mitra and Associates: Dhaka, Bangladesh; ORC Macro: Calverton, MD, USA, 2009.

84. National Institute of Population Research and Training (NIPORT); Mitra and Associates; ORC Macro. Bangladesh Demographic and Health Survey 2004; National Institute of Population Research and Training: Dhaka, Bangladesh; Mitra and Associates: Dhaka, Bangladesh; ORC Macro: Calverton, MD, USA, 2005.

85. Oguchi, M.; Murakami, S.; Sakanakura, H.; Kida, A.; Kameya, T. A preliminary categorization of end-of-life electrical and electronic equipment as secondary metal resources. Waste Manag. 2011, 31, 2150-2160. [CrossRef] [PubMed]

86. IDCOL. Infrastructure Development Company. Technical Specifications for Solar Home System (SHS) 2017. Available online: http://idcol.org/download/d31327d6638937dfd2c8a81ea1e35f37.pdf (accessed on 23 March 2017).

87. Batteiger, A. Towards a Waste Management System for Solar Home Systems in Bangladesh. In Decentralized Solutions for Developing Economies; Groh, S., Straeten, J., van der Lasch, B.E., Gershenson, D., Filho, W.L., Kammen, D.M., Eds.; Springer Proceedings in Energy, Springer International Publishing: Berlin/Heidelberg, Germany, 2015; pp. 133-140, ISBN 978-33-1-915963-8.

88. Asaduzzaman; Yunus, M.; Haque, A.K.E.; Abdul Malek Azad, A.; Neelormi, S.; Hossain, A. Power from the Sun: An Evaluation of Institutional Effectiveness and Impact of Solar Home Systems in Bangladesh; World Bank: Washington, DC, USA, 2013.

89. Magalini Frederico. (W)EEE Mass balance and market structure in Belgium-2011. Available online: http:/ / www.weee-forum.org/system/files/documents/2011_weee_mass_balance_and_market_ structure_in_belgium.pdf (accessed on 26 March 2017).

90. Smartflower. Available online: https://www.smartflower.com/assets/smartflowerpop-en8735aa9c879acc510f78f92a16d489e7.pdf (accessed on 21 March 2017).

91. UNU-IAS SCYCLE. Solving the E-waste Problem. E-waste World Map-Overview Bangladesh. Available online: http:/ / www.step-initiative.org/Overview_Bangladesh.html (accessed on 31 March 2017).

92. Islam, F. Battery Recycling Arrangements under IDCOL's Off-Grid Solar Home Systems Program. Available online: https://de.scribd.com/doc/134607480/Battery-Recycling-Arrangements-under-IDCOLs-Off-grid-Solar-Home-Systems-Program-Formanul-Islam (accessed on 23 March 2016).

93. IDCOL (Infrastructure Development Company Limited). Half-Yearly Report (January-June 2016) on Warranty Expired Battery Collection and New Battery Distribution under IDCOL's SHS Program; IDCOL: Dhaka, Bangladesh, 2016.

(c) 2018 by the authors. Licensee MDPI, Basel, Switzerland. This article is an open access article distributed under the terms and conditions of the Creative Commons Attribution (CC BY) license (http:// creativecommons.org/licenses/by/4.0/). 